\title{
Ocena zgodności z Konstytucją przepisów ustawy o ograniczeniu handlu w niedziele i święta oraz w niektóre inne dni w zakresie zarzutu o różnicowanie pracowników co do swobody wykonywania przez nich pracy w określone dni ${ }^{1}$
}

Evaluation of conformity to the Constitution of the provisions of the Act on Restriction of Trade on Sundays, Public Holidays and Certain Other Days, with regard to the plea that employees are differentiated as to their freedom to work during certain days: The President of the Lewiatan Confederation applied to the Constitutional Tribunal to evaluate certain provisions of the act, stating that these provisions provide for a differentiation of employees as to their freedom to work during certain days, what violates the following constitutional principles: the principle of labour protection, the principle of freedom to work, the principle of equality and the principle of proportionality. In the draft Sejm's position it was concluded, that these provisions conform to the Constitution. The introduction of diversification of commercial entities is related to the objective pursued by the legislator in this act, which is to ensure a rest day being conducive to the health and safety of employees. The constitutionality of the above solution is supported by the fact, that the legislator limited the group of exclusions to a catalogue of entities whose activity on Sundays and public holidays is rationally justified by social needs.

Keywords: trade, labour protection, public holidays, the Constitutional Tribunal

Słowa kluczowe: handel, ochrona pracy, święta, Trybunał Konstytucyjny

Doktor nauk prawnych, ekspert ds. legislacji BAS • jolanta.bucinska@sejm.gov.pl • https://orcid.org/0000-0002-2643-1437

Na podstawie art. 69 ust. 2 w związku z art. 42 pkt 3 ustawy z dnia 30 listopada 2016 r. o organizacji i trybie postępowania przed Trybunałem Konstytucyjnym (Dz. U. poz. 2072), w imieniu Sejmu Rzeczypospolitej Polskiej przedkładam wy-

1 Projekt stanowiska w sprawie wniosku Prezydenta Konfederacji Lewiatan z 17 maja 2018 r. dot. przepisów art. 3 pkt 7, art. 5, art. 6 i art. 18 ustawy z dnia 10 stycznia 2018 r. o ograniczeniu handlu w niedziele i święta oraz w niektóre inne dni (Dz. U. poz. 305) sporządzony 12 lutego 2019 r., sygn. akt K 10/18; BAS-WAKU 2717/18. 
jaśnienia w sprawie wniosku Prezydenta Konfederacji Lewiatan z 17 maja 2018 r. (sygn. akt K 10/18), jednocześnie wnosząc o uznanie, że:

- art. 3 pkt 7 i art. 18 ustawy z dnia 10 stycznia 2018 r. o ograniczeniu handlu w niedziele i święta oraz w niektóre inne dni (Dz. U. poz. 305) są zgodne $\mathrm{z}$ art. 2 Konstytucji,

- art. 5 ustawy powołanej w punkcie 1 jest zgodny z art. 65 ust. 1 w związku $\mathrm{z}$ art. $24 \mathrm{i}$ art. 31 ust. 3 Konstytucji,

- $\quad$ art. 6 ust. 1 ustawy powołanej w punkcie 1 jest zgodny $z$ art. 32 ust. 1 Konstytucji.

Ponadto wnoszę o umorzenie postępowania w pozostałym zakresie na podstawie art. 59 ust. 1 pkt 2 ustawy o organizacji i trybie postępowania przed Trybunałem Konstytucyjnym, ze względu na niedopuszczalność wydania wyroku.

\section{Uzasadnienie}

\section{Przedmiot kontroli}

1. W dniu 16 listopada 2018 r. do Kancelarii Sejmu wpłynęło zawiadomienie Prezes Trybunału Konstytucyjnego o wszczęciu postępowania przed Trybunałem Konstytucyjnym w sprawie wniosku Prezydenta Konfederacji Lewiatan (dalej: Wnioskodawca, Prezydent KL) z 17 maja 2018 r. (sygn. akt K 10/18).

Jako przedmiot kontroli zostały wskazane przepisy art. 3 pkt 7, art. 5, art. 6 i art. 18 ustawy z dnia 10 stycznia 2018 r. o ograniczeniu handlu w niedziele i święta oraz w niektóre inne dni (Dz. U. poz. 305; dalej: ustawa o ograniczeniu handlu w niedziele, u.o.h.n.).

2. Zgodnie $z$ art. 3 pkt 7 u.o.h.n.: „Ilekroć w ustawie jest mowa o: [...] wykonywaniu pracy w handlu oraz wykonywaniu czynności związanych $\mathrm{z}$ handlem w niedziele i święta w placówkach handlowych - należy przez to rozumieć wykonywanie takiej pracy lub takich czynności przez pracownika lub zatrudnionego w okresie 24 kolejnych godzin przypadających odpowiednio między godziną $24.00 \mathrm{w}$ sobotę a godziną $24.00 \mathrm{w}$ niedzielę, i między godziną $24.00 \mathrm{w}$ dniu bezpośrednio poprzedzającym święto a godziną 24.00 w święto".

Według art. 5 u.o.h.n.: „W niedziele i święta w placówkach handlowych:

1) handel oraz wykonywanie czynności związanych z handlem,

2) powierzanie pracownikowi lub zatrudnionemu wykonywania pracy w handlu oraz wykonywania czynności związanych z handlem - są zakazane";

Artykuł 6 u.o.h.n. stanowi: „1. Zakaz, o którym mowa w art. 5, nie obowiązuje:

1) na stacjach paliw płynnych;

2) w placówkach handlowych, w których przeważająca działalność polega na handlu kwiatami; 
3) w aptekach i punktach aptecznych;

4) w zakładach leczniczych dla zwierząt;

5) w placówkach handlowych, w których przeważająca działalność polega na handlu pamiątkami lub dewocjonaliami;

6) w placówkach handlowych, w których przeważająca działalność polega na handlu prasą, biletami komunikacji miejskiej, wyrobami tytoniowymi, kuponami gier losowych i zakładów wzajemnych;

7) w placówkach pocztowych w rozumieniu ustawy z dnia 23 listopada 2012 r. Prawo pocztowe (Dz. U. z 2017 r. poz. 1481 oraz z 2018 r. poz. 106 i 138);

8) w placówkach handlowych w obiektach infrastruktury krytycznej, o której mowa w ustawie z dnia 26 kwietnia 2007 r. o zarządzaniu kryzysowym (Dz. U. z 2017 r. poz. 209 i 1566);

9) w placówkach handlowych w zakładach hotelarskich;

10) w placówkach handlowych w zakładach prowadzących działalność w zakresie kultury, sportu, oświaty, turystyki i wypoczynku;

11) w placówkach handlowych organizowanych wyłącznie na potrzeby festynów, jarmarków i innych imprez okolicznościowych, tematycznych lub sportowo-rekreacyjnych, także gdy są one zlokalizowane w halach targowych;

12) w placówkach handlowych w zakładach leczniczych podmiotów leczniczych i innych placówkach służby zdrowia przeznaczonych dla osób, których stan zdrowia wymaga całodobowych lub całodziennych świadczeń zdrowotnych;

13) w placówkach handlowych na dworcach $w$ rozumieniu ustawy $z$ dnia 16 grudnia 2010 r. o publicznym transporcie zbiorowym (Dz. U. z 2017 r. poz. 2136 i 2371), w portach i przystaniach morskich w rozumieniu ustawy z dnia 20 grudnia 1996 r. o portach i przystaniach morskich (Dz. U. z 2017 r. poz. 1933) oraz $\mathrm{w}$ portach i przystaniach $\mathrm{w}$ rozumieniu ustawy $\mathrm{z}$ dnia 21 grudnia 2000 r. o żegludze śródlądowej (Dz. U. z 2017 r. poz. 2128) - w zakresie związanym z bezpośrednią obsługą podróżnych;

14) w centrach pierwszej sprzedaży ryb, w przypadku sprzedaży ryb z burty, w gospodarstwach rybackich, placówkach handlowych zajmujących się odbiorem produktów rybołówstwa i akwakultury oraz handlem takimi produktami;

15) w placówkach handlowych w portach lotniczych w rozumieniu ustawy z dnia 3 lipca 2002 r. - Prawo lotnicze (Dz. U. z 2017 r. poz. 959 i 1089 oraz z 2018 r. poz. 138);

16) w strefach wolnocłowych;

17) w środkach transportu, na statkach, a także na morskich statkach handlowych, statkach powietrznych, platformach wiertniczych i innych morskich budowlach hydrotechnicznych;

18) na terenie jednostek penitencjarnych;

19) w placówkach handlowych na terenie jednostek wojskowych;

20) w sklepach internetowych i na platformach internetowych; 
21) w przypadku handlu towarami $z$ automatów;

22) w przypadku rolniczego handlu detalicznego $w$ rozumieniu ustawy $z$ dnia 25 sierpnia 2006 r. o bezpieczeństwie żywności i żywienia (Dz. U. z 2017 r. poz. 149 i 60 );

23) w hurtowniach farmaceutycznych;

24) w okresie od dnia 1 czerwca do dnia 30 września każdego roku kalendarzowego - w placówkach handlowych prowadzących handel wyłącznie maszynami rolniczymi i częściami zamiennymi do tych maszyn;

25) w przypadku handlu kwiatami, wiązankami, wieńcami i zniczami przy cmentarzach;

26) w zakładach pogrzebowych;

27) w placówkach handlowych, w których handel jest prowadzony przez przedsiębiorcę będącego osobą fizyczną wyłącznie osobiście, we własnym imieniu i na własny rachunek;

28) w piekarniach, cukierniach i lodziarniach, w których przeważająca działalność polega na handlu wyrobami piekarniczymi i cukierniczymi;

29) w placówkach handlowych, w których przeważającą działalnością jest działalność gastronomiczna;

30) na terenie rolno-spożywczych rynków hurtowych prowadzonych przez spółki prawa handlowego, których przeważająca działalność polega na wynajmie i zarządzaniu nieruchomościami na użytek handlu hurtowego artykułami rolno-spożywczymi;

31) w placówkach handlowych prowadzonych przez podmioty nabywające towary na terenie rolno-spożywczych rynków hurtowych, o których mowa w pkt 30, w zakresie czynności związanych z handlem oraz powierzania pracownikowi lub zatrudnionemu wykonywania tych czynności;

32) w placówkach handlowych, w których jest prowadzony wyłącznie skup zbóż, buraków cukrowych, owoców, warzyw lub mleka surowego.

2. Przeważająca działalność, o której mowa w ust. 1 pkt 2, 5, 6, 28, 29 i 30, oznacza rodzaj przeważającej działalności wskazany we wniosku o wpis do krajowego rejestru urzędowego podmiotów gospodarki narodowej, o którym mowa w ustawie z dnia 29 czerwca 1995 r. o statystyce publicznej (Dz. U. z 2016 r. poz. 1068 oraz z 2017 r. poz. 60)";

Wreszcie zgodnie z art. 18 u.o.h.n.: „Ustawa wchodzi w życie z dniem 1 marca 2018 r".

\section{Zarzuty Wnioskodawcy}

1. Prezydent Konfederacji Lewiatan wnosi o stwierdzenie, że:

- art. 5 u.o.h.n. jest niezgodny z art. 24, art. 65 ust. 1, art. 32 oraz art. 31 ust. 3 Konstytucji w zakresie, w jakim różnicuje pracowników co do swobody wykonywania przez nich pracy w określone dni i w związku z tym narusza, jego 
zdaniem, zasadę ochrony pracy, wolność wykonywania pracy, zasadę równości oraz zasadę proporcjonalności;

- art. 6 u.o.h.n. jest niezgodny z art. 24, art. 65 ust. 1, art. 32 oraz art. 31 ust. 3 Konstytucji w zakresie, w jakim tworzy grupę podmiotów nieobjętych zakazem wynikającym $z$ art. 5 u.o.h.n. i różnicuje pracowników co do swobody wykonywania przez nich pracy w określone dni i w związku z tym narusza, w jego ocenie, zasadę ochrony pracy, wolność wykonywania pracy, zasadę równości oraz zasadę proporcjonalności;

- art. 3 pkt 7 u.o.h.n. jest niezgodny z art. 2 Konstytucji w zakresie, w jakim wywołuje niedające się usunąć wątpliwości interpretacyjne i w związku z tym narusza zasadę demokratycznego państwa prawnego, zasadę poprawnej legislacji, zasadę zaufania do państwa i stanowionego przez nie prawa;

- $\quad$ art. 18 u.o.h.n. jest niezgodny $\mathrm{z}$ art. 2 Konstytucji w zakresie, w jakim przewiduje rażąco krótką vacatio legis dla tego typu zmian legislacyjnych i w związku z tym narusza zasadę demokratycznego państwa prawnego, zasadę poprawnej legislacji, zasadę zaufania do państwa i stanowionego przez nie prawa.

Jednocześnie, w przypadku stwierdzenia przez Trybunał Konstytucyjny, że kwestionowane przepisy są niezgodne z Konstytucją, inicjator postępowania wnosi o stwierdzenie, że przepisy te pozostają w ścisłym funkcjonalnym związku z pozostałymi przepisami ustawy o ograniczeniu handlu w niedziele, $\mathrm{w}$ wyniku czego jej stosowanie jest niemożliwe i nie może stać się ona elementem polskiego porządku prawnego (wniosek, s. 1-2).

2. W ocenie Prezydenta KL art. 5 u.o.h.n. narusza zasadę wolności pracy (art. 65 ust. 1 Konstytucji), zasadę ochrony pracy (art. 24 Konstytucji) i zasadę proporcjonalności (art. 31 ust. 3 Konstytucji). Wnioskodawca podnosi, że zasadniczym skutkiem tego przepisu jest pozbawienie pracowników części dotychczas wykonywanej pracy, a w rezultacie zmniejszenie dochodów (wniosek, s. 9). Stwarza to niedopuszczalną z perspektywy art. 31 ust. 3 Konstytucji ingerencję w wolność pracy, która nie daje się „pogodzić z obrazem demokratycznego państwa prawa, tj. prowadzi do grupowych zwolnień w niektórych branżach, powoduje obniżenie dochodów lub zwiększenie wymiaru pracy w dni dotychczas wolniejsze, a także wywołuje skutek dyskryminacyjny, tworząc grupę uprzywilejowanych pracodawców i pracowników" (wniosek, s. 10). Zdaniem Wnioskodawcy kwestionowany przepis nie spełnia żadnej z przesłanek wymienionych w art. 31 ust. 3 Konstytucji. Uzasadnienia dla jego uchwalenia nie mogą stanowić względy bezpieczeństwa państwa, porządku publicznego, ochrony środowiska, zdrowia publicznego lub moralności publicznej ani ochrony wolności i praw innych osób (wniosek, s. 10-11). Inicjator postępowania wskazuje również, że zakwestionowana regulacja narusza konstytucyjny nakaz ochrony pracy przez to, że nie uwzględnia ekonomicznych i prawnych uwarunkowań działalności pracodawców. „To bowiem oni, w dominującej większości w społecznej gospodarce rynko- 
wej, jako podmioty niepubliczne, tworzą miejsca pracy, ponoszą ryzyko gospodarcze, troszczą się o utrzymanie ekonomicznego zysku pozwalającego utrzymać miejsca pracy oraz inwestować w rozwój zarówno w skali przedsiębiorstwa, jak i cywilizacyjny czy społeczny" (wniosek, s. 11).

3. W ocenie Wnioskodawcy w odniesieniu do art. 6 u.o.h.n. zachowują aktualność zarzuty podniesione w stosunku do art. 5 u.o.h.n. (naruszenia art. 65 ust. 1, art. 24, art. 31 ust. 3 Konstytucji). Ponadto zarzuca on naruszenie przez przywołany przepis zasady równości, wyrażonej w art. 32 ust. 1 Konstytucji. Zdaniem Prezydenta KL art. 6 u.o.h.n. wywołuje niedozwolony skutek w postaci dyskryminacji poprzez „stworzenie [...] grupy pracodawców/przedsiębiorców, którzy zachowują prawo do prowadzenia handlu w niedziele i święta oraz inne dni wskazane przez Ustawę [ustawa o ograniczeniu handlu w niedziele - dopisek J.B.], podczas gdy pozostała i znacznie szersza grupa pracodawców/przedsiębiorców będzie tego prawa pozbawiona” (wniosek, s. 12). Wnioskodawca podkreśla, że uzasadnienie projektu ustawy o ograniczeniu handlu w niedziele nie zawiera argumentów pozwalających zrozumieć przyczynę wyróżnienia akurat takiej grupy podmiotów, jak zawarta w art. 6 ust. 1 pkt 1-32 u.o.h.n. Oznacza to, zdaniem inicjatora postępowania, że kwestionowana regulacja nie spełnia wymogu racjonalności, a wyliczenie zawarte w powyższym przepisie nabiera cech arbitralności (wniosek, s. 13).

4. Wnioskodawca zarzuca przepisowi art. 3 pkt 7 u.o.h.n. niezgodność z zasadami: demokratycznego państwa prawnego, poprawnej legislacji, zaufania do państwa i stanowionego przez nie prawa (art. 2 Konstytucji), stwierdzając, że zakwestionowany przepis został „sformułowany w sposób, który uniemożliwia jego prawidłową interpretację, a co za tym idzie i implementację [...] Przypis [powinno być: przepis - uwaga J.B.] wprowadza definicję ram czasowych niedzieli i święta nie uwzględniając istniejącej już regulacji i definicji w Kodeksie Pracy” (wniosek, s. 14). Ponadto „zastosowanie normy odsyłającej z art. 2 Ustawy [ustawa o ograniczeniu handlu w niedziele - uwaga J.B.], która stanowi, że w zakresie nieuregulowanym w ustawie do wykonywania pracy przez pracowników w placówkach handlowych w niedziele i święta stosuje się przepisy ustawy z dnia 26 czerwca 1974 r. - Kodeks pracy (Dz. U. z 2016 r. poz. 1666, z późn. zm.) nie prowadzi do żadnych wniosków interpretacyjnych, skoro oba te terminy są konkurencyjnie zdefiniowane w obu aktach prawnych" (wniosek, s. 14).

5. Również przepisowi art. 18 u.o.h.n. Wnioskodawca zarzuca niezgodność z zasadami: demokratycznego państwa prawnego, poprawnej legislacji, zaufania do państwa i stanowionego przez nie prawa (art. 2 Konstytucji). Prezydent KL argumentuje, że brak odpowiednio długiej vacatio legis w odniesieniu do ustawy o ograniczeniu handlu w niedziele, która „pogarsza sytuację określonych grup podmiotów - części pracodawców i części pracowników, stanowi naruszenie art. 2 Konstytucji” (wniosek, s. 15). Przepis art. 18 u.o.h.n., zdaniem Wnioskodawcy, przewiduje rażąco krótką vacatio legis dla tego typu zmian legislacyjnych, 
gdyż pracodawcy nie mogli ze stosownym wyprzedzeniem racjonalnie zaplanować swoje działania, unikając chaosu organizacyjnego oraz strat finansowych (wniosek, s. 16).

\section{Analiza formalnoprawna}

1. W zakresie analizy formalnoprawnej należy zauważyć przede wszystkim, że niniejsze postępowanie zostało zainicjowane wnioskiem pochodzącym od podmiotu o ograniczonej legitymacji procesowej, co nakazuje dokonanie oceny jego dopuszczalności z perspektywy art. 191 ust. 1 pkt 4 i ust. 2 Konstytucji. Na tej podstawie kontrolę konstytucyjności mogą zainicjować ogólnokrajowe władze organizacji pracodawców, jeżeli kwestionowany akt normatywny dotyczy spraw objętych ich zakresem działania. Zgodnie z art. 1 ust. 1 i art. 2 ust. 1 Statutu Konfederacji Lewiatan (dalej: Statut) Konfederacja ta stanowi organizację pracodawców, w rozumieniu ustawy z dnia 23 maja 1991 r. o organizacjach pracodawców (t.j. Dz. U. 2015, poz. 2029), prowadzącą działalność na terenie Rzeczypospolitej Polskiej. Prezydent KL jest jej statutowym organem (art. 13 ust. 1 Statutu). Prezydent KL, działając jednoosobowo, uprawniony jest m.in. do składania oświadczeń woli i reprezentowania Konfederacji na zewnątrz (art. 20 Statutu), dodatkowo art. 21 ust. 8 Statutu przyznaje mu ogólne uprawnienie do „podejmowania decyzji w innych sprawach nie zastrzeżonych do kompetencji pozostałych organów Konfederacji”. Ponieważ prawo wystąpienia z wnioskiem do Trybunału Konstytucyjnego nie jest zastrzeżone do kompetencji jakiegokolwiek innego organu statutowego Konfederacji, trzeba uznać, że to Prezydent Konfederacji Lewiatan stanowi ogólnokrajową władzę tej konkretnej organizacji pracodawców, legitymowaną do występowania z wnioskami do Trybunału Konstytucyjnego.

Weryfikując, czy zakwestionowany akt normatywny dotyczy zakresu spraw objętych zakresem działania organizacji, należy wskazać na art. 4 Statutu, zgodnie z którym podstawowymi celami Konfederacji Lewiatan są: ochrona praw i reprezentowanie interesów zrzeszonych organizacji pracodawców wobec związków zawodowych, pracowników oraz organów władzy publicznej, jak również prowadzenie działań na rzecz rozwoju rynku i przeciwdziałanie bezrobociu. Cele te uszczegóławiają postanowienia art. 5 ust. 1 i 3 Statutu, zgodnie z którymi do zadań Wnioskodawcy należy również reprezentowanie na szczeblu ogólnokrajowym społecznych i gospodarczych interesów pracodawców oraz oddziaływanie na kształtowanie ustawodawstwa gospodarczego i socjalnego wspierającego harmonijny rozwój gospodarki polskiej i stosunków pracy oraz uwzględniającego prawa i interesy zrzeszonych pracodawców. Wnioskodawca wskazuje, że kwestionowane przepisy adresowane są $\mathrm{w}$ szczególności do pracodawców, wymuszając zmianę dotychczasowej praktyki wykonywania stosunków pracy i ograniczając możliwość pracy w niedziele, święta oraz pozostałe dni wskazane w ustawie o ograniczeniu handlu w niedziele. Dodaje on, że w większości przypadków praktyka handlowa jest realizowana przez pracowników, czyli osoby zatrudnio- 
ne w ramach stosunku pracy (wniosek, s. 5). Poczynione ustalenie pozwala na przyjęcie, iż kwestionowana regulacja, przewidując wyłączenie możliwości prowadzenia handlu w niedziele i święta oraz niektóre pozostałe dni w placówkach handlowych, dotyczy bez wątpienia spraw objętych zakresem działania Konfederacji Lewiatan, mieszcząc się jednocześnie w sprawach z zakresu stosunków między pracodawcami i pracownikami.

2. Przy ocenie wniosku pod względem formalnoprawnym refleksji wymagają niektóre z przywołanych przez Wnioskodawcę wzorców kontroli. Zgodnie z art. 47 ust. 2 ustawy z dnia 30 listopada 2016 r. o organizacji i trybie postępowania przed Trybunałem Konstytucyjnym (Dz. U. poz. 2072; dalej: ustawa o TK), uzasadnienie zarzutu zawierać powinno przywołanie treści kwestionowanego wnioskiem przepisu wraz z jego wykładnią, przywołanie treści wzorców kontroli wraz z ich wykładnią, określenie problemu konstytucyjnego i zarzutu niekonstytucyjności, jak też wskazanie argumentów lub dowodów na poparcie zarzutu niekonstytucyjności. Należy przypomnieć, że Trybunał Konstytucyjny jest związany zarzutami sformułowanymi w piśmie procesowym (wniosku, pytaniu prawnym, skardze konstytucyjnej) inicjatora postępowania, niemniej zarzuty te mogą podlegać rozpatrzeniu tylko wtedy, jeżeli zostały należycie uzasadnione. Jak podkreślił Trybunał Konstytucyjny: „Przesłanka odpowiedniego uzasadnienia zarzutów nie powinna być traktowana powierzchownie i instrumentalnie. Przytaczane w piśmie procesowym argumenty mogą być mniej lub bardziej przekonujące [...], lecz zawsze muszą być argumentami «nadającymi się» do rozpoznania przez Trybunał Konstytucyjny” (wyrok TK z 19 października 2010 r., sygn. akt P 10/10). Konieczność uzasadnienia zarzutu sformułowanego $\mathrm{w}$ piśmie inicjującym postępowanie przed Trybunałem Konstytucyjnym wynika z domniemania konstytucyjności norm prawnych oraz z obowiązujących w postępowaniu przed TK zasad skargowości i kontradyktoryjności (art. 67 ustawy o TK).

Wnioskodawca w petitum pisma sformułował zarzut naruszenia art. 32 Konstytucji w odniesieniu do art. 5 oraz art. 6 u.o.h.n. Należy jednak zauważyć, że w stosunku do pierwszego z przywołanych przepisów poddanych kontroli, w treści uzasadnienia nie powołał on żadnych argumentów na jego poparcie. Brak uzasadnienia co do naruszenia określonego wzorca kontroli, mimo że został on wymieniony w petitum pisma wszczynającego postępowanie, oznacza niezrealizowanie przez Wnioskodawcę obowiązku wynikającego z art. 47 ust. 2 Konstytucji, które powinno skutkować umorzeniem postępowania na podstawie art. 59 ust. 1 pkt 2 ustawy o TK, ze względu na niedopuszczalność wydania wyroku. W stosunku do drugiej z zakwestionowanych regulacji jako wzorzec kontroli wskazany został cały art. 32 Konstytucji, składający się z dwóch ustępów. Z uzasadnienia wniosku wynika jednak, że Prezydent KL odnosi niezgodność art. 6 u.o.h.n. nie do całej treści przepisu art. 32 Konstytucji, a jedynie do jego ustępu 1, w którym została zadekretowana zasada równości wobec prawa. Wprawdzie Try- 
bunał Konstytucyjny niekiedy przyjmuje w swoim orzecznictwie, że przepis ten stanowi pewną „całość normatywną" (zob. wyroki TK z: 23 października 2001 r., sygn. akt K 22/01; 28 maja 2002 r., sygn. akt P 10/01; 2 kwietnia 2003 r., sygn. akt K 13/02; 10 czerwca 2003 r., sygn. akt K 16/02; 28 kwietnia 2009 r., sygn. akt K 27/07), niemniej wyraża on także pogląd, że nieuzasadnione na gruncie Konstytucji zróżnicowanie podmiotów charakteryzujących się tą samą cechą relewantną nie stanowi samo przez się naruszenia zasady niedyskryminacji, zawartej w art. 32 ust. 2 Konstytucji. Z uwagi na powyższe wzorcem kontroli powinien być wyłącznie art. 32 ust. 1 Konstytucji. Tak ukształtowana korekta zarzutu została odzwierciedlona w petitum niniejszego stanowiska.

3. Wątpliwości natury formalnoprawnej budzi także kwestia prawidłowego określenia pozostałych wzorców kontroli powoływanych w odniesieniu do art. 5 i art. 6 u.o.h.n. Mimo iż Wnioskodawca stawia zarzuty naruszenia zasady wolności pracy (art. 65 ust. 1 Konstytucji), zasady ochrony pracy (art. 24 Konstytucji) oraz zasady proporcjonalności (art. 31 ust. 3 Konstytucji), zgłoszona przezeń argumentacja względem art. 5 u.o.h.n. koncentruje się w głównej mierze na nieproporcjonalnej ingerencji w prawo do ochrony pracy, wolność wyboru i wykonywania zawodu oraz wyboru miejsca pracy poprzez ustanowienie zakazu pracy w niedziele, święta i pozostałe dni. Uwzględniając zakres stawianych we wniosku zarzutów, wzorcem kontroli należy zatem uczynić art. 65 ust. 1 w związku $\mathrm{z}$ art. $24 \mathrm{i}$ art. 31 ust. 3 Konstytucji.

$\mathrm{Z}$ treścią przywołanych wzorców kontroli wnioskodawca konfrontuje także przepis art. 6 u.o.h.n. Przy formułowaniu zarzutów ograniczył się jednak do stwierdzenia, że zachowują one swoją aktualność także w stosunku do art. 6 u.o.h.n. (wniosek, s. 12). Argumentacja, do której odwołuje się Wnioskodawca, dotyczy jednak innego przedmiotu kontroli, którym jest przepis wyrażający zakaz handlu w niedziele i święta (art. 5 u.o.h.n.). W uzasadnieniu wniosku poddano analizie jedynie zarzut niezgodności z zasadą równości wyrażoną $\mathrm{w}$ art. 32 ust. 1 Konstytucji, nie wskazując żadnych dodatkowych argumentów na rzecz niezgodności z art. 24, art. 31 ust. 3 oraz art. 65 ust. 1 Konstytucji. Pozwala to uznać, że istotę niezgodności kwestionowanej regulacji Wnioskodawca wiąże wyłącznie z treścią art. 32 ust. 1 Konstytucji. W związku z brakiem uzasadnienia w stosunku do zarzutów dotyczących pozostałych przywołanych wzorców kontroli postępowanie należy umorzyć na podstawie art. 59 ust. 1 pkt 2 ustawy o TK, ze względu na niedopuszczalność wydania wyroku.

Ponadto, w zakresie odnoszącym się do art. 6 u.o.h.n. wymaga korekty przedmiot kontroli. Należy zauważyć, że zakres normowania wskazanego przepisu jest szerszy od kwestionowanego przez Wnioskodawcę, który swoje zastrzeżenia odnosi do nierównego, w jego ocenie, traktowania podmiotów prowadzących działalność handlową i tym samym kwestionuje zasadność katalogu wyłączeń ustawowych ujętych w art. 6 ust. 1 u.o.h.n. Natomiast pomija on kwestię pojęcia „przeważającej działalności” uregulowanej w ust. 2 tego artykułu. W konsekwen- 
cji należy przyjąć, że postępowanie powinno być prowadzone jedynie w zakresie badania zgodności art. 6 ust. 1 u.o.h.n. z art. 32 ust. 1 Konstytucji.

4. Następny problem formalny dotyczy zarzutu niezgodności art. 3 pkt 7 u.o.h.n. z zasadami demokratycznego państwa prawnego, poprawnej legislacji oraz zaufania do państwa i stanowionego przez nie prawa (art. 2 Konstytucji). Z konstytucyjnej zasady demokratycznego państwa prawa wywodzona jest zasada poprawnej legislacji, która obejmuje dyrektywy wiążące prawodawcę w procesie stanowienia prawa, mające na celu w pierwszym rzędzie ochronę słusznych interesów adresatów nowych uregulowań prawnych. Można do nich zaliczyć dyrektywę dochowania przepisanego trybu stanowienia aktu normatywnego czy przyznania adresatom odpowiedniego czasu na dostosowanie swoich działań do nowych regulacji. $Z$ zasady poprawnej legislacji wywodzi się także nakaz dostatecznej określoności prawa, którego treścią jest spoczywający na prawodawcy obowiązek sformułowania przepisów w sposób poprawny pod względem językowym i logicznym, precyzyjny i jasny (zob. wyrok TK z 11 stycznia 2000 r., sygn. akt K 7/99). Konkretyzując ten obowiązek, Trybunał Konstytucyjny dodaje, że wymóg jasności oznacza nakaz tworzenia przepisów klarownych i zrozumiałych dla ich adresatów, którzy od racjonalnego ustawodawcy oczekiwać mogą stanowienia norm niebudzących wątpliwości co do treści nakładanych obowiązków i przyznawanych praw tak, by ich treść była oczywista i pozwalała na ich wyegzekwowanie (zob. wyrok TK z 21 marca 2001 r., sygn. akt K 24/00).

Odnosząc powyższe kryteria do niniejszej sprawy, należy przyjąć, że Wnioskodawca formułuje zarzut naruszenia zasady określoności przepisów prawa. Analiza uzasadnienia wniosku daje bowiem podstawę do sformułowania stwierdzenia, że zastrzeżenia Wnioskodawcy budzą: zakres obowiązków adresatów kwestionowanej normy oraz spełnienie wymogów technicznej strony legislacyjnej (sprzeczność w układzie horyzontalnym). Ze względu na brak osobnych argumentów, które wykazywałyby naruszenie zasad: demokratycznego państwa prawnego, poprawnej legislacji oraz ochrony zaufania do państwa i stanowionego przez nie prawa, art. 3 pkt 7 u.o.h.n. powinien zostać poddany weryfikacji pod względem zgodności z wywodzoną z art. 2 Konstytucji zasadą określoności prawa.

5. Podobnie korekty wymaga zarzut podniesiony przez Wnioskodawcę w stosunku do art. 18 u.o.h.n., któremu Wnioskodawca zarzuca niezgodność z zasadą demokratycznego państwa prawnego, zasadą poprawnej legislacji, zasadą zaufania do państwa i stanowionego przez nie prawa (art. 2 Konstytucji). Z uzasadnienia wniosku wynika, że Wnioskodawca koncentruje się na wykazaniu niezgodności przywołanego przepisu z zasadą odpowiedniej vacatio legis, tj. zasadą, która stanowi element składowy zasad poprawnej legislacji oraz zaufania obywatela do państwa i stanowionego przez nie prawa. W związku z powyższym należy zmienić sposób oznaczenia wzorca kontroli, co zostało uwzględnione w przeprowadzonej analizie zgodności. Pozwala to określić wzorzec kontroli w sposób właściwy i bez uszczerbku dla przedstawionych we wniosku argumentów. 
6. Na marginesie rozważań warto odnotować, że do Sejmu wpłynął poselski projekt ustawy o uchyleniu ustawy o ograniczeniu handlu w niedziele i święta oraz niektóre inne dni z dnia 22 marca 2018 r. (RPU VIII, poz. 2423), przewidujący w szczególności utratę mocy w całości ustawy z dnia 10 stycznia 2018 r. o ograniczeniu handlu w niedziele.

\section{Wzorce kontroli}

1. Jak już wskazano, Prezydent KL konfrontuje zakwestionowane we wniosku przepisy z art. 2 Konstytucji i wywodzonymi z niego zasadami: zaufania obywatela do państwa i stanowionego przez nie prawa, określoności prawa i odpowiedniej vacatio legis, z art. 24 Konstytucji, gwarantującym ochronę pracy, z art. 31 ust. 3 Konstytucji, wyrażającym zasadę proporcjonalności, z art. 32 ust. 1 Konstytucji, wyrażającym zasadę równości wobec prawa, oraz z art. 65 ust. 1 Konstytucji, zapewniającym wolność pracy.

2. Wskazany jako wzorzec kontroli art. 2 Konstytucji głosi, że: „Rzeczpospolita Polska jest demokratycznym państwem prawnym, urzeczywistniającym zasady sprawiedliwości społecznej”. Jest to jedna z najbardziej pojemnych zasad konstytucyjnych, której treść podlega ciągłej wykładni organów bezpośrednio stosujących ustawę zasadniczą (W. Sokolewicz, M. Zubik, Komentarz do art. 2 [w:] Konstytucja Rzeczypospolitej Polskiej. Komentarz, t. II, red. L. Garlicki, M. Zubik, Warszawa 2016, s. 94). Z przywołanej klauzuli generalnej demokratycznego państwa prawnego judykatura i doktryna wyodrębniły zasady pochodne. Nie zostały one expressis verbis ujęte w tekście Konstytucji, ale w sposób immanentny wynikają z jej aksjologii oraz istoty demokratycznego państwa prawnego (E. Morawska, Klauzula państwa prawnego w Konstytucji RP na tle orzecznictwa Trybunału Konstytucyjnego, Toruń 2003, s. 394.). W sytuacji, gdy wszystkie one mogą samodzielnie stanowić wzorce kontroli, niezbędne dla oceny konstytucyjności kontrolowanego przepisu jest wyraźne określenie wzorca kontroli. W rozpatrywanej sprawie Wnioskodawca precyzuje w uzasadnieniu pisma, że art. 2 Konstytucji stanowi wzorzec kontroli w zakresie, w jakim wynika $\mathrm{z}$ niego zasada zaufania obywateli do państwa i stanowionego przez nie prawa, zasada określoności prawa oraz zasada odpowiedniej vacatio legis.

Orzecznictwo TK jest zgodne co do tego, że zasada ochrony zaufania obywateli do państwa i stanowionego przez nie prawa należy do kanonu zasad składających się na pojęcie państwa prawnego w znaczeniu, które występuje w art. 2 Konstytucji (wyrok TK z 20 grudnia 1999 r., sygn. akt K 4/99). Zasada ta określana jest w orzecznictwie TK także jako zasada lojalności państwa wobec adresata norm prawnych (np. wyroki TK z: 7 lutego 2001 r., sygn. akt K 27/00; 21 grudnia 2005 r., sygn. akt K 45/05; 28 lutego 2012 r., sygn. akt K 5/11). Istota przywołanej zasady wyraża się w „stanowieniu i stosowaniu prawa w taki sposób, by nie stawało się ono swoistą pułapką dla obywatela, który powinien móc układać swoje sprawy w zaufaniu, że nie naraża się na prawne skutki niedające się prze- 
widzieć w momencie podejmowania decyzji i że jego działania są zgodne z obowiązującym prawem oraz także w przyszłości będą uznawane przez porządek prawny. Przyjmowane przez ustawodawcę nowe unormowania nie mogą zaskakiwać adresatów, którzy powinni mieć czas na dostosowanie się do zmienionych regulacji i spokojne podjęcie decyzji co do dalszego postępowania" (wyrok TK z 15 lutego 2005 r., sygn. akt K 48/04; zob. także wyrok TK z 25 listopada 1997 r., sygn. akt K 26/97).

Trybunał wielokrotnie również podkreślał, że analizowana zasada opiera się na „pewności prawa, a więc takim zespole cech przysługujących prawu, które zapewniają jednostce bezpieczeństwo prawne; umożliwiają jej decydowanie o swoim postępowaniu w oparciu o pełną znajomość przesłanek działania organów państwowych oraz konsekwencji prawnych, jakie ich działania mogą pociągnąć za sobą. Jednostka winna mieć możliwość określenia zarówno konsekwencji poszczególnych zachowań i zdarzeń na gruncie obowiązującego w danym momencie stanu prawnego jak też oczekiwać, że prawodawca nie zmieni ich w sposób arbitralny. Bezpieczeństwo prawne jednostki związane z pewnością prawa umożliwia więc przewidywalność działań organów państwa, a także prognozowanie działań własnych. W ten sposób urzeczywistniana jest wolność jednostki, która według swoich preferencji układa swoje sprawy i przyjmuje odpowiedzialność za swoje decyzje, a także jej godność, poprzez szacunek porządku prawnego dla jednostki, jako autonomicznej, racjonalnej istoty [...]. Wartości te przy zmianie prawa, prawodawca narusza wtedy, gdy jego rozstrzygnięcie jest dla jednostki zaskoczeniem, bo w danych okolicznościach nie mogła go przewidzieć, szczególnie zaś wtedy, gdy przy jego podejmowaniu prawodawca mógł przypuszczać, że gdyby jednostka przewidywała zmianę prawa, byłaby inaczej zdecydowała o swoich sprawach [...]. Chodzi tu więc nie o ten aspekt pewności prawa, który odnosi się do względnej stabilności porządku prawnego mający związek z zasadą legalności, lecz o pewność prawa rozumianą jako pewność tego, iż w oparciu o obowiązujące prawo obywatel może kształtować swoje stosunki życiowe. W tym drugim sensie prawo pewne (pewność prawa) oznacza także prawo sprawiedliwe" (wyrok TK z 14 czerwca 2000 r., sygn. akt P 3/00; zob. także wyroki z: 25 kwietnia 2001 r., sygn. akt K 13/01; 19 grudnia 2002 r., sygn. akt K 33/02; 29 czerwca 2005 r., sygn. akt SK 34/04).

Niewątpliwie ustawodawca cieszy się względną swobodą stanowienia prawa odpowiadającego celom politycznym i gospodarczym, a Trybunał Konstytucyjny nie jest powołany do kontrolowania celowości i trafności przyjmowanych przezeń rozwiązań, co wielokrotnie podkreślał, stwierdzając m.in., że „granice [...] swobody zakreślone są [...] innymi normami konstytucyjnymi, a w szczególności zasadami demokratycznego państwa prawnego i sprawiedliwości społecznej” (orzeczenie TK z 9 stycznia 1996 r., sygn. akt K 18/95). Równocześnie wskazał jednak, że „ustawodawca posiada całkowitą swobodę w kształtowaniu treści porządku prawnego pod warunkiem, że nie narusza Konstytucji”, a „ocena celowości i trafności rozstrzygnięć parlamentu wykracza poza zakres kompeten- 
cji sądownictwa konstytucyjnego” (powołany wyżej wyrok TK w sprawie o sygn. akt K 5/99). Trybunał Konstytucyjny kilkakrotnie wywiódł ponadto, że „nie jest powołany do kontrolowania celowości i trafności rozwiązań przyjmowanych przez ustawodawcę. Punktem wyjścia dla jego orzeczeń jest zawsze założenie racjonalnego działania ustawodawcy i domniemanie zgodności ustaw z konstytucją. Jeżeli jednak konstytucja nakłada na ustawodawcę obowiązek stanowienia prawa zgodnego $\mathrm{z}$ wymaganiami o tak generalnym charakterze, jak demokratyczne państwo prawne czy zaufanie obywatela do państwa, to nakazuje to Trybunałowi Konstytucyjnemu interweniować w tych wszystkich przypadkach, gdy ustawodawca przekroczy zakres swej swobody regulacyjnej w sposób na tyle drastyczny, że naruszenie wspomnianych klauzul konstytucyjnych stanie się ewidentne" (m.in. wyrok TK z 8 kwietnia 1998 r., sygn. akt K 10/97).

Zdaniem Trybunału Konstytucyjnego nie tylko poszczególne przepisy powinny być sformułowane poprawnie z punktu widzenia językowego i logicznego, lecz wymóg logicznej poprawności i spójności należy stawiać całemu aktowi prawnemu. „Nie ulega wątpliwości, że ocena «logicznej poprawności» uwarunkowana znajomością prawideł logiki formalnej, musi też opierać się na kryteriach zdroworozsądkowych" (wyrok TK z 17 maja 2005 r., sygn. akt P 6/04).

2. Zasada określoności prawa stanowi dyrektywę prawidłowej legislacji oraz jeden $z$ elementów zasady ochrony zaufania do państwa i stanowionego przez nie prawa (wyroki TK z: 28 października 2009 r., sygn. akt K 32/08; 29 maja 2012 r., sygn. akt SK 17/09; 29 lipca 2014 r., sygn. akt P 49/13). Wynika z niej spoczywający na prawodawcy obowiązek formułowania przepisów prawnych, zwłaszcza dotyczących wolności i praw jednostki lub przewidujących możliwość stosowania wobec niej sankcji, w sposób poprawny, jasny i precyzyjny, tym samym zapewniający przewidywalność skutków jego zastosowania (zob. wyroki TK z: 11 stycznia 2000 r., sygn. akt K 7/99; 12 czerwca 2002 r., sygn. akt P 13/01)). Z tak ujętej zasady określoności wynika, że każdy przepis prawny powinien być skonstruowany poprawnie z punktu widzenia językowego i logicznego. Przepis powinien być klarowny i zrozumiały dla adresata, niebudzący wątpliwości co do treści nakładanych obowiązków i przyznawanych praw. Związana z jasnością precyzja przepisu winna przejawiać się również w konkretności nakładanych obowiązków i przyznawanych praw, tak aby pozwalała ona na ich egzekwowanie (zob. wyrok TK z 21 marca 2001 r., sygn. akt K 24/00). Konkretyzując ten obowiązek, Trybunał Konstytucyjny wskazał, że wymóg jasności oznacza nakaz tworzenia przepisów w sposób kompletny, precyzyjny i jednoznacznie definiujący wszystkie, w tym podmiotowe, znamiona czynów zagrożonych karą (zob. wyrok TK z 26 kwietnia 1995 r., sygn. akt K 11/94).

Niemniej nie każde naruszenie powyższej zasady stanowi jednocześnie złamanie konstytucyjnej zasady prawidłowej legislacji, a jedynie takie, które jest istotne. Do naruszenia wymogu określoności przepisów prawa dochodzi w sytuacji, gdy przepis jest sformułowany w sposób niejasny i nieprecyzyjny w stopniu 
powodującym istotne wątpliwości prawne, a także gdy posługuje się pojęciami niezdefiniowanymi albo niezrozumiałymi (zob. wyroki TK z: 30 października 2001 r., sygn. akt K 33/00; 28 października 2009 r., sygn. akt Kp 3/09). Rygor stosowania tej zasady zależy także od rodzaju zagadnień będących przedmiotem regulacji prawnej. Niewątpliwie i w sposób kategoryczny odnosi się on do relacji między państwem a obywatelami jako adresatami przepisu prawnego. Stąd wszystkie przepisy ograniczające realizację wolności i praw jednostki muszą być dostatecznie określone (wyrok TK z 10 listopada 1998 r., sygn. akt K 39/97, zob. W. Sokolewicz, M. Zubik, Komentarz do art. 2, op. cit., s. 147-148).

Wymóg określoności nie wyklucza posługiwania się przez ustawodawcę pojęciami nieostrymi lub odwołującymi się do funkcjonujących w społeczeństwie przekonań i ocen, jeśli mają one ugruntowaną w świadomości prawnej jednostek podstawę aksjologiczną, z której wynika konkretny imperatyw normatywny (zob. wyrok TK z 15 września 1999 r., sygn. akt K 11/99). Dopuszcza się również używanie pojęć, które ze swej istoty wymagają wykładni, odwołują się do regulacji zawartych w innych gałęziach prawa (zob. wyrok TK z 12 września 2005 r., sygn. akt SK 13/05) lub innych aktach prawnych (postanowienie TK z 23 listopada 2004 r., sygn. akt Tw 25/04). Natomiast będzie sprzeczne z zasadą określoności odesłanie, które zawiera sformułowanie niedookreślone, prowadząc do niedających się usunąć wątpliwości co do zakresu naruszenia wolności człowieka (wyrok TK z 7 października 2015 r., sygn. akt K 12/14).

W wyroku z 6 października 2015 r. (sygn. akt SK 54/13) Trybunał Konstytucyjny sformułował swoisty test określoności prawa, który wymaga odpowiedzi na trzy pytania dotyczące: po pierwsze - precyzyjności regulacji prawnej (konkretność regulacji praw i obowiązków, tak by ich treść pozwalała na wyegzekwowanie); po drugie - jasności przepisu (zrozumiałość dla adresatów) oraz po trzecie - legislacyjnej poprawności (spełnienie wymogów co do strony technicznolegislacyjnej).

3. Wymóg ustanowienia odpowiedniej vacatio legis nie został wyrażony expressis verbis w ustawie zasadniczej. W świetle dotychczasowego orzecznictwa Trybunału Konstytucyjnego i poglądów przedstawicieli doktryny nie budzi jednak wątpliwości, że instytucja ta jest elementem składowym zasady demokratycznego państwa prawnego wyrażonej w art. 2 Konstytucji i wynika z zasad zaufania obywateli do państwa i stanowionego przez nie prawa oraz przyzwoitej (poprawnej) legislacji (zob. wyrok TK z 12 czerwca 2002 r., sygn. akt P 13/01). Vacatio legis oznacza okres spoczywania aktu prawnego, a więc czas pomiędzy jego ogłoszeniem w odpowiednim dzienniku publikacyjny a wejściem w życie. Ustanowienie tego okresu służy realizacji dwóch zasadniczych celów. Po pierwsze, ma umożliwiać adresatom norm prawnych zapoznanie się z nowym prawem, a po drugie zapewniać im czas na przystosowanie się do zmienionych regulacji i podjęcie odpowiednich decyzji co do dalszego postępowania (zob. wyrok TK z 21 marca 2000 r., sygn. akt K 4/99). 
W praktyce kluczowym elementem tej zasady staje się określenie „odpowiedniości” vacatio legis, a więc ustalenie, ile - przy uwzględnieniu treści nowych norm i wywołanych nimi skutków prawnych - powinien wynosić okres pomiędzy ogłoszeniem a wejściem w życie. W orzecznictwie Trybunału Konstytucyjnego podkreśla się, że „ocena, czy w konkretnym wypadku długość okresu vacatio legis jest odpowiednia, jest uzależniona od całokształtu okoliczności, w szczególności zaś od przedmiotu i treści unormowań przewidzianych w nowych przepisach, w tym od tego, jak dalece różnią się one od unormowań dotychczasowych [...] «Odpowiedniość» vacatio legis należy oceniać w konkretnej sytuacji, z uwzględnieniem nie tylko przedmiotu i treści nowej ustawy, lecz także kręgu podmiotów prawa, których normy ustawy dotyczą" (wyrok TK z 20 grudnia 1999 r., sygn. akt K 4/99, a także z 31 stycznia 2006 r., sygn. akt K 23/03; 20 stycznia 2010 r., sygn. akt Kp 6/09).

Podkreśla się, że nakaz zachowania odpowiedniej vacatio legis nie ma charakteru bezwzględnego. Zgodnie z utrwalonym orzecznictwem Trybunału uzasadnionym okolicznościami, które uzasadniają większą swobodę ustawodawcy w kwestii ustalenia vacatio legis, jest ważny interes publiczny, którego nie można wyważyć z interesem jednostki (zob. wyrok TK z 25 czerwca 2002 r., sygn. akt $\mathrm{K} 45 / 01$ ). Ustawodawca może wręcz zrezygnować z vacatio legis, jeżeli przemawia za tym ważny interes publiczny. Standard w tym względzie w sposób ogólny wyznacza ustawa z dnia 20 lipca 2000 r. o ogłaszaniu aktów normatywnych i niektórych innych aktów prawnych (t.j. Dz. U. 2017, poz. 1523), przewidująca 14 dni jako minimalny okres vacatio legis (art. 4 ust. 1). W dotychczasowym orzecznictwie sąd konstytucyjny przyjmował, że w zakresie określania daty wejścia ustawy w życie ustawodawcy przysługuje duży margines swobody. Nie może być to jednak arbitralność nieznajdująca dostatecznego wyjaśnienia w motywach legislatora i okolicznościach sprawy (zob. wyrok TK z 17 grudnia 2008 r., sygn. akt P 16/08).

Trybunał Konstytucyjny niejednokrotnie podkreślał, że ocena, czy przewidziana $\mathrm{w}$ ustawie vacatio legis jest odpowiednia, powinna zostać dokonana ze szczególną ostrożnością: „Jeżeli vacatio legis odpowiada generalnym założeniem przyjętym w art. 4 ust. 1 ustawy z dnia 20 lipca 2000 r. o ogłaszaniu aktów normatywnych i niektórych innych aktów prawnych, uznanie przez Trybunał, że doszło do naruszenia art. 2 Konstytucji mogłoby nastąpić tylko w rażących przypadkach" (wyrok TK z 16 września 2003 r., sygn. akt K 55/02).

Przy ocenie zgodności aktów normatywnych z obowiązkiem zachowania odpowiedniej vacatio legis należy także wziąć pod uwagę możliwość zapoznania się przez zainteresowanych $\mathrm{z}$ treścią projektowanej regulacji prawnej w trakcie postępowania ustawodawczego. Inaczej należy oceniać na przykład rozwiązania prawne poddane uprzednio konsultacjom społecznym, inaczej zaś regulacje wprowadzone na ostatnich etapach procesu legislacyjnego. Jak wskazał Trybunał: „W pierwszym przypadku zainteresowani dowiadują się o zamierzeniach 
ustawodawcy z wyprzedzeniem i mogą w praktyce rozpocząć dostosowywanie się do nowej regulacji zaraz po jej ustanowieniu przez parlament, a więc jeszcze przed podpisaniem ustawy przez Prezydenta i przed ogłoszeniem jej w Dzienniku Ustaw” (wyrok TK z 31 stycznia 2006 r., sygn. akt K 23/03).

4. Zgodnie z art. 24 Konstytucji: „Praca znajduje się pod ochroną Rzeczypospolitej Polskiej. Państwo sprawuje nadzór nad warunkami wykonywania pracy”. Wspomniany przepis Konstytucji wyraża zasadę ochrony pracy, która powinna znajdować swoje urzeczywistnienie na poziomie ustawodawstwa zwykłego. W konsekwencji ustanawia on kompetencję władz państwowych do ingerowania w kształt stosunków pracy i stanowi podstawę wprowadzania ograniczeń wobec zasady swobody umów i równości prawnej stron w stosunkach umownych.

Ochronna funkcja prawa pracy polega przede wszystkim na działaniu jego norm w sposób chroniący interesy zawodowe i socjalne pracowników. Jak wskazuje Trybunał Konstytucyjny, ustawodawca dysponuje w tej materii szerokim zakresem swobody regulacyjnej (zob. wyrok TK z 12 lipca 2010 r., sygn. akt P 4/10). Należy mieć jednak na uwadze, że konstytucyjnie statuowaną zasadę ochrony pracy należy rozpatrywać w kontekście innych zasad konstytucyjnych, w tym zasady sprawiedliwości społecznej, która z kolei nakazuje objęcie silniejszą ochroną strony słabszej stosunku pracy, tj. pracownika. Ciążąca na państwie powinność ochrony pracy oznacza przy tym - przede wszystkim - obowiązek ochrony pracowników. Sprowadza się on do stworzenia przez państwo określonych gwarancji prawnych dotyczących zarówno ochrony osoby pracownika, jak i jego interesów. Nie oznacza to oczywiście, że sytuacja prawna pracodawców znajduje się poza zakresem zastosowania ochrony przewidzianej w art. 24 Konstytucji. Pojęcie ochrony należy rozumieć jako podejmowanie środków prawnych, politycznych i faktycznych osłabiających negatywne skutki, jakie dla pracowników niesie silniejsza ekonomiczna pozycja pracodawcy. Innymi słowy, sprawowanie ochrony oznacza obowiązek państwa do ingerowania w stosunki między pracownikami i pracodawcami wszędzie tam, gdzie okaże się to konieczne dla zapewnienia należytej równowagi uczestników procesu pracy (zob. L. Garlicki, M. Zubik, Komentarz do art. 24 [w:] Konstytucja Rzeczypospolitej Polskiej. Komentarz, t. I, red. L. Garlicki, M. Zubik, Warszawa 2016, s. 590).

5. Artykuł 31 ust. 3 Konstytucji stanowi: „Ograniczenia w zakresie korzystania z konstytucyjnych wolności i praw mogą być ustanawiane tylko w ustawie i tylko wtedy, gdy są konieczne w demokratycznym państwie dla jego bezpieczeństwa lub porządku publicznego, bądź dla ochrony środowiska, zdrowia i moralności publicznej, albo wolności i praw innych osób. Ograniczenia te nie mogą naruszać istoty wolności i praw".

Istotą tego unormowania jest wyznaczenie granic ingerencji władzy publicznej w sferę wolności i praw konstytucyjnych (tzw. granic ograniczeń) poprzez ogólne określenie przesłanek, których spełnienie jest konieczne do wprowadzenia ograniczeń praw i wolności jednostki. Został on skonstruowany z trzech części, 
z których pierwsza to ustalenie przesłanki formalnej (wymóg ustawowej formy ograniczeń), druga - określenie przesłanek materialnych (poprzez specyfikację pojęcia „interesu publicznego”) oraz trzecia - wskazanie maksymalnych granic dla wprowadzania ograniczeń (nakaz szanowania zasady proporcjonalności oraz zakaz naruszania „istoty” praw i wolności), (L. Garlicki, K. Wojtyczek, Komentarz do art. 31 [w:] Konstytucja Rzeczypospolitej Polskiej. Komentarz, t. II, red. L. Garlicki, M. Zubik, Warszawa 2016, s. 72). Jest to przepis dopuszczający zawężenie zakresu stosowania wolności i praw konstytucyjnie zagwarantowanych i tym samym musi być interpretowany zgodnie z zasadami wykładni wyjątków, w szczególności przy uwzględnieniu zakazu rozszerzającej interpretacji jego postanowień.

W orzecznictwie polskiego sądu konstytucyjnego nie budzi wątpliwości, że przywołany przepis statuuje w sposób w pełni samodzielny i całościowy zasadę proporcjonalności (wyrok TK z 12 stycznia 1999 r., sygn. akt P 2/98). Świadczy o tym jego treść, która wskazuje, że ograniczenia konstytucyjnych praw i wolności mogą być ustanawiane tylko wtedy, „gdy są konieczne w demokratycznym państwie”. W ocenie TK zasada proporcjonalności: „Z jednej strony stawia [...] przed prawodawcą każdorazowo wymóg stwierdzenia rzeczywistej potrzeby dokonania w danym stanie faktycznym ingerencji w zakres prawa bądź wolności jednostki. Z drugiej zaś winna być ona rozumiana jako wymóg stosowania takich środków prawnych, które będą skuteczne, a więc rzeczywiście służące realizacji zamierzonych przez prawodawcę celów. Ponadto chodzi tu o środki niezbędne, w tym sensie, że chronić będą określone wartości w sposób, bądź w stopniu, który nie mógłby być osiągnięty przy zastosowaniu innych środków. Niezbędność to również skorzystanie ze środków jak najmniej uciążliwych dla podmiotów, których prawa lub wolności ulegną ograniczeniu. Ingerencja w sferę statusu jednostki musi więc pozostawać w racjonalnej i odpowiedniej proporcji do celów, których ochrona uzasadnia dokonane ograniczenie. [...] «Konieczność», którą wyraża art. 31 ust. 3 Konstytucji mieści więc w sobie postulat niezbędności, przydatności i proporcjonalności sensu stricto wprowadzanych ograniczeń” (wyrok TK z 12 stycznia 1998 r., sygn. akt P 2/98).

Z powyższego orzeczenia wynika, że dla oceny, czy doszło do naruszenia zasady proporcjonalności, konieczne jest udzielenie odpowiedzi na pytanie, czy kwestionowana norma spełnia trzy wymagania: przydatności, konieczności i proporcjonalności sensu stricto. Te trzy kryteria stosowane powinny być do konkretnych unormowań odnoszących się do poszczególnych typów wolności i praw jednostki. Trybunał wskazuje tym samym, że zasada proporcjonalności ma charakter relatywny, bo różnicuje zakres dopuszczalnej ingerencji w zależności od tego, jakie wolności bądź prawa stają się przedmiotem tej ingerencji (orzeczenie TK z 26 kwietnia 1995 r., sygn. akt K 11/94). W orzecznictwie konstytucyjnym przyjmuje się, że im cenniejsze jest dobro ograniczane i wyższy jest stopień tego ograniczenia, tym cenniejsza musi być wartość uzasadniająca ograniczenia (wyrok TK z 25 lipca 2013 r., sygn. akt P 56/11). 
6. Artykuł 32 ust. 1 Konstytucji statuuje fundamentalną w demokratycznym państwie prawnym zasadę równości. Zgodnie z jego brzmieniem: „Wszyscy są wobec prawa równi. Wszyscy mają prawo do równego traktowania przez władze publiczne”. Konstytucyjna zasada równości wobec prawa ujęta w art. 32 ust. 1 wyraża nakaz, aby wszystkie podmioty prawa (adresaci norm prawnych), charakteryzujące się daną cechą istotną w równym stopniu, były traktowane równo, a więc według jednakowej miary, bez zróżnicowań zarówno dyskryminujących, jak i faworyzujących. W orzecznictwie TK przyjmuje się, że: „[r]ówność oznacza akceptację różnego traktowania przez prawo różnych podmiotów (adresatów norm prawnych), bo równe traktowanie przez prawo tych samych podmiotów pod pewnym względem oznacza $z$ reguły różne traktowanie tych samych podmiotów pod innym względem. [...] różne traktowanie przez prawo określonych grup (klas) podmiotów powinno być jednak uzasadnione w tym sensie, że musi być oparte na uznanych kryteriach oceny klasyfikacji różnicującej podmioty prawa” (orzeczenie TK z 9 marca 1988 r., sygn. akt U 7/87; także wyrok TK z 6 maja 1998 r., sygn. akt K 37/97).

W orzecznictwie konstytucyjnym podkreśla się konieczność badania kontekstu zastosowania zasady równości. „Równość w rozumieniu konstytucyjnym nie ma charakteru abstrakcyjnego i absolutnego, funkcjonuje zawsze w pewnym kontekście sytuacyjnym i musi odnosić się do nakazów (zakazów) lub uprawnień przynależnych określonym jednostkom (ich grupom) w porównaniu ze statusem innych jednostek (grup). Postulat równości nie może być utożsamiany z nakazem identyczności praw wszystkich jednostek nie tylko z tego względu, że każda regulacja prawna w istocie wprowadza zróżnicowanie między podmiotami. Nakaz identycznego ukształtowania uprawnień czy obowiązków wszystkich jednostek w warunkach obiektywnie istniejących zróżnicowań o charakterze naturalnym (np. cech osobowościowych jednostek) czy faktycznym (sytuacyjnym, np. miejsce jednostki w społeczeństwie) kolidowałby niejednokrotnie z zasadą sprawiedliwości społecznej, a także z zasadą racjonalnego ustawodawcy. A zatem dopóki zróżnicowania odpowiadają obiektywnie istniejącym różnicom między adresatami norm prawnych, nie mamy do czynienia z naruszeniem zasady równości. Problem naruszenia tej zasady powstaje wówczas, gdy wprowadzone do systemu prawnego zróżnicowania dotyczą podmiotów podobnych. Kluczowe dla oceny, czy doszło do naruszenia konstytucyjnej zasady równości, jest więc zawsze ustalenie cechy istotnej, która przesądzałaby o uznaniu określonych (porównywanych) podmiotów za podobne lub odmienne. Jeśli wynik tego ustalenia prowadzi do wniosku, że porównywane podmioty są podobne, wówczas konieczne staje się zbadanie, czy wprowadzenie zróżnicowania jest uzasadnione. Zróżnicowanie podmiotów prawa charakteryzujących się wspólną cechą istotną jest bowiem dopuszczalne (i nie narusza zasady równości) pod warunkiem sine qua non jasno sformułowanego kryterium (stanowiącego podstawę zróżnicowania), które można w świetle zasad i wartości konstytucyjnych uzasadnić odpo- 
wiednio przekonującymi argumentami” (wyrok TK z 23 marca 2010 r., sygn. akt SK 47/08).

W orzecznictwie Trybunału Konstytucyjnego został ustalony katalog warunków, które w świetle zasady równości musi spełniać kryterium stanowiące podstawę zróżnicowania. Po pierwsze, musi mieć ono charakter relewantny, a zatem musi pozostawać $\mathrm{w}$ bezpośrednim związku z celem i zasadniczą treścią przepisów, w których zawarta jest kontrolowana norma, i służyć realizacji tego celu i treści. Kryterium to musi mieć zatem charakter racjonalnie uzasadniony, a nie arbitralny (zob. orzeczenie TK z 12 grudnia 1994 r., sygn. akt K 3/94). Po drugie, kryterium to musi mieć charakter proporcjonalny. Waga interesu, któremu ma służyć zróżnicowanie sytuacji adresatów normy, musi więc pozostawać w odpowiedniej proporcji do wagi interesów, które zostaną naruszone w wyniku nierównego potraktowania podmiotów podobnych. Po trzecie, kryterium to musi pozostawać $\mathrm{w}$ związku z zasadami, wartościami i normami konstytucyjnymi uzasadniającymi odmienne traktowanie podmiotów podobnych (zob. np. wyrok TK z 23 października 1995 r., sygn. akt K 4/95). Niespełnienie tych warunków świadczy o tym, że dokonane przez prawodawcę zróżnicowanie jest niedopuszczalne (wyrok TK z 23 marca 2010 r., sygn. akt SK 47/08).

7. Zagwarantowana $\mathrm{w}$ art. 65 ust. 1 Konstytucji wolność pracy wyraża się w wolności wyboru i wykonywania zawodu oraz wyboru miejsca pracy. Wyjątki od niej określa ustawa. Przyjmuje się, że przepis ten reguluje tzw. pozytywny aspekt wolności pracy. W tym ujęciu praca jest formą zarobkowej aktywności na rzecz innego podmiotu, stanowiącej podstawowe źródło egzystencji danej osoby i jej najbliższych, nawet jeśli nie następuje to $\mathrm{w}$ ramach stosunku pracy w rozumieniu prawa pracy. Pełna wolność pracy to nie tylko brak przymusu, ale również brak ograniczeń, które uniemożliwiają podmiotom prawnym wykonywanie określonego zawodu czy zatrudnienia, nie przymuszając ich jednocześnie do robienia czegoś innego.

Wykładni zasady wolności pracy Trybunał Konstytucyjny dokonał m.in. w wyroku z 23 czerwca 1999 r. (sygn. akt K 30/98), w którym przyjąl, że art. 65 ust. 1 Konstytucji wyraża pozytywny aspekt wolności pracy i obejmuje możliwość wyboru rodzaju pracy (element kwalifikatywny), pracodawcy (element podmiotowy) i miejsca pracy (element przestrzenny) (zob. także wyrok TK z 27 lipca 2006 r., sygn. akt SK 43/04). Aspekt przestrzenny jest interpretowany w doktrynie dwojako. W wąskim rozumieniu może być ujmowany jako „swoboda przemieszczania się w celu podjęcia pracy zarobkowej" (zob. Z. Góral, Podstawowe zasady indywidualnego prawa pracy, Warszawa 2010, s. 569-570). Treścią wolności pracy w tym ujęciu jest też bez wątpienia możliwość podejmowania pracy zarobkowej poza podstawowym miejscem zatrudnienia. Poza aspektem ściśle przestrzennym, wolność pracy obejmuje również swobodę wyboru pracodawcy (zakładu pracy), dla którego ma być świadczona praca, a więc wolność pracy w aspekcie podmiotowym. Szersze ujęcie wolności wyboru miejsca pra- 
cy dostrzega także niekiedy Trybunał Konstytucyjny, przyjmując, że „do istoty wolności wyboru miejsca pracy należy [...] między innymi swoboda wyboru pracodawcy (podmiotu zatrudniającego)" (wyrok TK z 18 października 2011 r., sygn. akt SK 24/09, zob. także L. Garlicki, S. Jarosz-Żukowska, Komentarz do art. 65 [w:] Konstytucja Rzeczypospolitej Polskiej. Komentarz, t. II, red. L. Garlicki, M. Zubik, Warszawa 2016, s. 395).

Aspekt podmiotowy wolności pracy rozumiany jako swoboda wyboru pracodawcy, oznacza nie tylko możliwość wyboru podmiotu zatrudniającego, ale także zmiany czy rezygnacji z zatrudnienia, jak również pozostawania więcej niż w jednym stosunku pracy, a więc podejmowania dodatkowego zatrudnienia (zob. wyrok TK z 23 czerwca 1999 r., sygn. akt K 30/98).

Treść konstytucyjnej wolności wyboru pracodawcy pozostaje w ścisłym związku z gwarancją wolności wyboru i wykonywania zawodu. Oznacza to, że ustawodawca ma „obowiązek zapewnić możliwość wyboru zawodu i miejsca pracy w sposób wolny od zewnętrznej ingerencji, w możliwie najszerszym zakresie" (wyrok TK z 19 marca 2001 r., sygn. akt K 32/00). Wykonywanie zawodu można uznać za kwalifikowaną postać wolności wykonywania pracy, gdyż nie wszystkie rodzaje prac łączą się z wykonywaniem konkretnego zawodu. Zatem możliwość wprowadzania wyjątków, o których jest mowa w postanowieniach konstytucyjnych, dotyczy głównie wykonywania zawodu. Jak podkreśla Trybunał Konstytucyjny, wolność pracy nie ma charakteru absolutnego i może podlegać reglamentacji prawnej (wyrok TK z 19 października 1999 r., sygn. akt SK 4/99). Wprowadzanie drogą ustawową wyjątków dotyka najczęściej kwestii określania i egzekwowania warunków, od których zależy możliwość uzyskania uprawnień do wykonywania danego zawodu, wyznaczania sposobów i metod wykonywania zawodu, a także kwestii określania powinności wobec państwa czy samorządu terytorialnego. Nie jest natomiast prawnie dopuszczalne ograniczenie dostępu nowych osób do danego zawodu. Gwarancja wolności wykonywania zawodu nie kłóci się z reglamentowaniem przez państwo spraw związanych z wykonywaniem zawodu i statusem osób je wykonujących, a wręcz zakłada istnienie tego typu regulacji. W szczególności dotyczy to zawodów zaufania publicznego. Zdaniem Trybunału Konstytucyjnego z wolnością wykonywania zawodu zgodne jest ustalanie sytuacji prawnej osób zawód ten wykonujących, także w zakresie poddawania ich obowiązkowi ubezpieczenia społecznego i narzucania im obowiązku opłacania składek. Nakładanie na obywateli różnego rodzaju obciążeń w okresie ich aktywności zawodowej wiąże się z realizacją przez państwo obowiązku zapewnienia każdemu środków utrzymania na starość.

Ponadto $\mathrm{z}$ art. 65 ust. 1 Konstytucji wynika także zakaz stanowienia ograniczeń polegających na ustanawianiu norm, które chociaż nie mają charakteru formalnego zakazu, to uniemożliwiają lub znacznie utrudniają korzystanie z wolności pracy przez wyodrębnioną kategorię osób. Regulacje tego rodzaju podlegać muszą także ocenie $z$ punktu widzenia zasady proporcjonalności oraz 
aksjologii konstytucji (zob. wyroki TK z: 23 czerwca 1999 r., sygn. akt SK 30/99; 29 listopada 2011 r., sygn. akt SK 15/09; 6 listopada 2012 r., sygn. akt SK 29/11; także L. Garlicki, S. Jarosz-Żukowska, Komentarz do art. 65, op. cit., s. 399-400).

Wolność pracy nie ma charakteru absolutnego. Wynika to z treści art. 65 ust. 1 zdanie drugie Konstytucji, zgodnie z którą ustawa może określić wyjątki od wolności pracy. Oznacza to, że ustawodawca może reglamentować zarówno kwestie wyboru, jak i wykonywania pracy (zawodu). Konstytucja zakłada więc, że wolność pracy musi podlegać ograniczeniom, ale zakres dopuszczalnych ograniczeń trzeba rozpatrywać z uwzględnieniem ogólnych wymagań, jakie wynikają z art. 31 ust. 3 (zob. ibidem, s. 397). Zachowanie formy ustawowej jest spełnieniem jednego $\mathrm{z}$ wymagań dla wprowadzenia ograniczeń wolności pracy. Poza wymogiem wyłączności ustawy wszelkie ingerencje w sferę wolności wykonywania zawodu wymagają: powiązania ograniczenia z ochroną jednej z wartości czy interesów wskazanych w art. 31 ust. 3 Konstytucji oraz zachowania wymogu niezbędności (proporcjonalności) ograniczenia, czyli, innymi słowy, poszanowania zakazu arbitralności. Konieczne jest wreszcie poszanowanie „istoty” regulowanej wolności (zob. wyroki TK z: 23 czerwca 1999 r., sygn. akt SK 30/99; 19 października 1999 r., sygn. akt SK 4/99; 19 marca 2001 r., sygn. akt K 32/00; 26 lipca 2004 r., sygn. akt U 16/02; 18 października 2010 r., sygn. akt K 1/09).

\section{Analiza zgodności}

\section{- 1. Zarzut niezgodności art. 5 u.o.h.n. z art. 65 ust. 1 (zasada wolności pracy) w związku z art. 24 (zasada ochrony pracy) i art. 31 ust. 3 (zasada proporcjonalności) Konstytucji}

1.1. Istotny wpływ na ocenę kwestionowanego przepisu ma ustalenie zakresu swobody legislacyjnej ustawodawcy w odniesieniu do możliwości kształtowania dni wolnych od pracy. W pierwszej kolejności należy wskazać na treść art. 24 Konstytucji, który stanowi, że praca znajduje się pod ochroną Rzeczypospolitej Polskiej, a państwo sprawuje nadzór nad warunkami wykonywania pracy. Przepis ten zawiera deklarację, obejmując swoją ochroną warunki, zakres i treść świadczenia i przyjmowania pracy w ramach zarówno stosunku pracy, jak też świadczenia pracy, które odbywa się w obrębie stosunków cywilnoprawnych oraz innego rodzaju zatrudnienia (zob. Konstytucje Rzeczypospolitej Polskiej oraz komentarz do Konstytucji RP z 1997 r., red. J. Boć, Wrocław 1998, s. 61). Oznacza to, że na państwie ciąży obowiązek ochrony pracowników jako „słabszej” strony stosunku pracy, a w konsekwencji obowiązek stwarzania przez państwo gwarancji prawnych ochrony, w tym ochrony przed niezgodnymi z prawem bądź nieuzasadnionymi działaniami pracodawców (zob. wyrok TK z 18 października 2005 r., sygn. akt SK 48/03). Zgodnie z poglądami doktryny art. 24 Konstytucji wymaga, aby $\mathrm{z}$ jednej strony nie były stanowione unormowania bądź podejmowane działania przekreślające lub nadmiernie ograniczające ochronę pracy przez 
państwo, a z drugiej - aby całokształt obowiązujących unormowań ustawowych zapewniał należyty poziom ochrony pracy (zob. W. Sokolewicz, M. Zubik, Komentarz do art. 2, op. cit., s. 94). Pojęcie „nadzoru” nad warunkami wykonywania pracy oznacza kompetencję organów państwa do „władczego wypowiadania się o warunkach wykonywanej pracy” (J. Boć [w:] Konstytucje Rzeczypospolitej Polskiej oraz komentarz do Konstytucji RP z 1997 roku, red. J. Boć, Wrocław 1998, s. 61).

Za Trybunałem należy też przypomnieć, że art. 24 Konstytucji ma charakter normy programowej, wyznaczającej kierunek polityki państwa w zakresie stosunków pracowniczych (zob. postanowienie TK z 27 września 2005 r., sygn. akt Tw 26/05), która jest adresowana do władz państwowych i nie wynika z niej jakiekolwiek prawo podmiotowe, przysługujące jednostkom lub zbiorowym podmiotom występującym w ustroju pracy (zob. postanowienia TK z 24 kwietnia i 14 czerwca 2003 r., sygn. akt Ts 144/02). W wyroku z 12 lipca 2011 r. (sygn. akt K 26/09) Trybunał podkreśla, że art. 24 Konstytucji należy również postrzegać w kontekście innych konstytucyjnych zasad prawa pracy, jak zasada wolności pracy i jej gwarancje (art. 65 Konstytucji), prawo do bezpiecznych warunków pracy i urlopu (art. 67 Konstytucji), a także prawo do ochrony zdrowia (art. 68 Konstytucji), czy prawo osób niepełnosprawnych do pomocy państwa (art. 69). Dopiero uwzględnienie innych konstytucyjnych unormowań w zakresie pracy, z których największe znaczenie ma art. 65 Konstytucji, pozwala wyznaczyć konstytucyjny poziom ochrony pracy), gdyż sam art. 24 Konstytucji nie wyznacza poziomu ochrony. Przewidziana w art. 65 ust. 1 Konstytucji wolność wyboru i wykonywania zawodu oraz wyboru miejsca pracy nie ma charakteru prawa podmiotowego, lecz eksponuje zasadę wolności pracy oraz formułuje szczegółowe gwarancje ochrony pracy (zob. L. Garlicki, S. Jarosz-Żukowska, Komentarz do art. 65, op. cit., s. 389). Wolność pracy nie jest prawem absolutnym, a Konstytucja dopuszcza od niej wyjątki, nie dając jednak bezpośrednich wskazówek co do tego, jakie rodzaje aktywności mogą być nimi objęte. Granicą ich ustanawiania są przesłanki określone w art. 31 ust. 3 Konstytucji oraz wartości konstytucyjne.

Jedną z przywołanych w art. 31 ust. 3 Konstytucji wartości są prawa i wolności innych osób, w tym prawo do wypoczynku, skonkretyzowane w art. 66 ust. 2 Konstytucji w postaci prawa do określonych w ustawie dni wolnych od pracy. W dniach wolnych od pracy pracownik jest zwolniony z obowiązku świadczenia pracy. Celem ich wprowadzenia jest zapewnienie pracownikowi możliwości regeneracji sił fizycznych i psychicznych (zob. B. Banaszak, Konstytucja Rzeczypospolitej Polskiej. Komentarz, Warszawa 2012, s. 401). Pojęcie „dni wolne od pracy” odnosi się do tygodniowego rytmu pracy, a także do tradycji różnego rodzaju „dni świątecznych”, ale konkretyzacja tych pojęć została pozostawiona ustawodawcy zwykłemu (zob. wyrok TK z 2 października 2012 r., sygn. akt K 27/11). Konstytucja nie określa, jakie dni są wolne od pracy, ile takich dni powinno przysługiwać pracownikowi w roku, nie ustanawia żadnych kategorii dni wolnych od 
pracy (święta religijne, święta państwowe i niedziele). Nie daje też podstawy do określenia funkcji (społecznych, kulturowych, gospodarczych, religijnych) dni wolnych od pracy (ibidem). Zagadnienia czasu wolnego od pracy normuje samodzielnie ustawodawca, bezpośrednio wskazując dni wolne (np. niedziela, święta) lub wyznaczając je w sposób pośredni (np. wprowadzając pięciodniowy tydzień pracy, bez wskazania, który dzień tygodnia ma stanowić drugi, obok niedzieli, dzień wolny od pracy). Określenia sposobu ustalania dni wolnych od pracy, a co za tym idzie ich liczby, ustawodawca dokonuje zgodnie z przyjętymi przez siebie założeniami polityki prawa. Może on zatem zwiększać lub zmniejszać liczbę dni wolnych od pracy, realizując ustalone przez siebie cele społeczno-gospodarcze. Także sposób redukcji lub dodania dni wolnych od pracy, w stosunku do poprzedniego stanu prawnego, zależy od prawodawcy.

Artykuł 66 ust. 2 Konstytucji nie wiąże, jak powiedziano, dni wolnych od pracy z niedzielami i świętami, pozostawiając w tym względzie swobodę ustawodawcy. Toteż Trybunał Konstytucyjny, jakkolwiek dostrzega odmienną od dnia świątecznego rolę niedzieli, uznaje, że „niezależnie [...] od funkcji święta i niedzieli, jako dni wolnych od pracy, istotą prawa gwarantowanego art. 66 ust. 2 Konstytucji jest uprawnienie pracownika do nieświadczenia pracy w tym dniu. Prawo to może być jednak ograniczone zgodnie z art. 31 ust. 3 Konstytucji przez zobowiązanie pewnych kategorii pracowników do świadczenia pracy także w niedziele lub święta" (wyrok TK z 2 października 2012 r., sygn. akt K 27/11). Ma to znaczenie w przypadku zbiegu dnia wolnego w związku z pięciodniowym tygodniem pracy ze świętem przypadającym w tym dniu. Trybunał przyjmuje jednak, że „niezależnie, czy zostanie on wykorzystany na cele rekreacyjne, czy też celebrację święta lub dla innych celów ważnych dla pracownika istota gwarantowanego konstytucją prawa do ustawowo dni wolnych od pracy, czyli powstrzymanie się od świadczenia pracy, została zachowana" (wyrok TK z 2 października 2012 r., sygn. akt K 27/11; także L. Garlicki, S. Jarosz-Żukowska, Komentarz do art. 66 [w:] Konstytucja Rzeczypospolitej Polskiej. Komentarz, t. II, red. L. Garlicki, M. Zubik, Warszawa 2016, s. 418-419). Podsumowując, należy stwierdzić, że istotą dnia wolnego od pracy jest uzyskanie przez pracownika czasu, którym może on swobodnie dysponować, a ze względu na to, że dzień wolny ma służyć także regeneracji sił pracownika, musi być on wyznaczany periodycznie.

Z przedstawionej analizy wynika, że przy konkretyzacji ochrony pracy ustawodawcy zwykłemu pozostawia się znaczną swobodę regulacyjną $\mathrm{w}$ zakresie regulacji czasu pracy i dni wolnych. W powiązaniu z zasadą domniemania konstytucyjności ustaw oznacza to, że uznanie niekonstytucyjności danego przepisu jest możliwe tylko wtedy, gdy zostaną przedstawione argumenty w sposób niewątpliwy wykazujące, że regulacja ustawowa prowadzi do naruszenia „istoty” danego prawa.

1.2. Ustawa o ograniczeniu handlu w niedziele odnosi się do kwestii czasu wolnego od pracy, określając „zasady dotyczące ograniczenia handlu oraz wy- 
konywania czynności związanych z handlem w placówkach handlowych w niedziele i święta oraz w dniu 24 grudnia i w sobotę bezpośrednio poprzedzającą pierwszy dzień Wielkiej Nocy" (art. 1 u.o.h.n.). Zgodnie z art. 3 pkt 1 u.o.h.n. przez placówkę handlową należy rozumieć obiekt, w którym jest prowadzony handel oraz są wykonywane czynności związane z handlem, w szczególności: sklep, stoisko, stragan, hurtownię, skład węgla, skład materiałów budowlanych, dom towarowy, dom wysyłkowy, biuro zbytu - jeżeli w takiej placówce praca jest wykonywana przez pracowników lub zatrudnionych (a więc także pracowników tymczasowych i zatrudnionych na podstawie cywilnoprawnej). Przez handel należy rozumieć proces sprzedaży polegający na wymianie towaru lub wyrobu na środki pieniężne (art. 3 pkt 2 u.o.h.n.), zaś wykonywanie czynności związanych $\mathrm{z}$ handlem oznacza wykonywanie w placówce handlowej czynności bezpośrednio związanych $\mathrm{z}$ handlem przez pracownika lub zatrudnionego, a także wykonywanie $\mathrm{w}$ takiej placówce przez pracownika lub zatrudnionego czynności związanych z magazynowaniem towarów lub ich inwentaryzacją (art. 3 pkt 3 u.o.h.n.). Treść normatywna art. 5 u.o.h.n. sprowadza się do zakazu prowadzenia działalności handlowej oraz zakazu powierzania pracownikowi lub zatrudnionemu wykonywania pracy w handlu, bądź wykonywania czynności związanych $\mathrm{z}$ handlem, nawet gdy ich powierzenie jest bezpłatne (zob. także art. 4 u.o.h.n.). Należy zwrócić uwagę na fakt, że zakaz ten odnosi się do pracowników placówek handlowych, bez względu na to, kto jest ich pracodawcą. Dlatego też dotyczy także pracowników tymczasowych oraz firm zewnętrznych. Ustawa zakazuje prowadzenia działalności handlowej nie tylko przedsiębiorcom (handlowcom), ale także świadczenia pracy pracownikom, innym zatrudnionym oraz innym osobom wykonującym pracę na rzecz placówek handlowych. Zakaz pracy odnosi się do osób wykonujących pracę w ramach zatrudnienia niepracowniczego, cywilnoprawnego oraz pracowników tymczasowych, pracowników nie zatrudnionych przez przedsiębiorców prowadzących działalność handlową, np. firm zewnętrznych (zob. A. Świątkowski, Kodeks pracy. Komentarz, 2018, Legalis, komentarz do art. 1519b; J. Sobczyk [w:] Kodeks pracy. Komentarz, red. J. Sobczyk, 2018, Legalis, komentarz do art. 1519b). Wykaz dni świątecznych, w których obowiązuje zakaz pracy, zawiera ustawa z 18 stycznia 1951 r. o dniach wolnych od pracy (t.j. Dz.U. 2015, poz. 90, ze zm.; dalej: ustawa o dniach wolnych od pracy). Zakaz pracy obowiązuje wyłącznie w dni świąteczne wymienione w tej ustawie.

Ustawodawca uregulował także wyjątki od zakazu handlu w niedziele i święta. Katalog wyłączeń ustawowych zawiera art. 6 ust. 1 u.o.h.n., obejmujący ponad trzydzieści pozycji. Wyjątki od zakazu handlu odnoszą się do rodzajów placówek handlowych oraz terminów, w których obowiązuje zakaz prowadzenia działalności handlowej. Należy zwrócić uwagę, że zakaz pracy w niedziele i święta w placówkach handlowych nie ma zastosowania wobec osób fizycznych, których działalność gospodarcza polega na prowadzeniu takich placówek - właścicieli oraz osób z nimi współpracujących. Naruszenie zakazu handlu w niedziele i święta 
może być karane grzywną w wysokości od tysiąca do stu tysięcy złotych (art. 10 ust. 1-2 u.o.h.n.) albo podlega karze ograniczenia wolności (art. 218a ustawy z dnia 6 czerwca 1997 r. - Kodeks karny, t.j. Dz.U. 2018, poz. 1600, ze zm.). Sankcje administracyjne i karne mogą być nakładane na osoby lub podmioty powierzające wykonywanie pracy pracownikom lub zatrudnionym $w$ handlu albo związanych z handlem w placówkach handlowych. Państwowa Inspekcja Pracy została zobowiązana do przeprowadzania, bez uprzedzenia i o każdej porze dnia i nocy, kontroli przestrzegania przepisów prawa pracy, w szczególności przepisów ustawy o ograniczeniu handlu w niedziele w zakresie powierzania pracownikowi lub zatrudnionemu wykonywania pracy w handlu lub wykonywania czynności związanych z handlem w placówkach handlowych (zob. A. Świątkowski, Kodeks pracy, op. cit., komentarz do art. 1519b).

Zakazy handlu nie obowiązują $\mathrm{w}$ terminach wymienionych $\mathrm{w}$ przepisach art. 7 ust. 1 , art. 8 ust. 1 , art. 16 ust. 1 i art. 17 ust. 1 u.o.h.n. Generalnie zakaz handlu nie obowiązuje w kolejne dwie niedziele poprzedzające pierwszy dzień Bożego Narodzenia, niedzielę bezpośrednio poprzedzającą pierwszy dzień Wielkiej Nocy oraz ostatnią niedzielę przypadającą w styczniu, kwietniu, czerwcu i sierpniu. W dniu 24 grudnia i w sobotę bezpośrednio poprzedzającą pierwszy dzień Wielkiej Nocy zakazany jest handel po godzinie 14.00. W pierwszym roku obowiązywania ustawy o ograniczeniu handlu, w okresie od 1 marca 2018 r. do 31 grudnia 2018 r. zakaz prowadzenia działalności handlowej nie obowiązuje w pierwszą i ostatnią niedzielę każdego miesiąca kalendarzowego. W kolejnym okresie - tj. od 1 stycznia 2019 r. do 31 grudnia 2019 r. - zakaz ten nie obowiązuje w ostatnią niedzielę każdego miesiąca kalendarzowego. Od 1 stycznia 2020 r. obowiązywać będą zasady sformułowane w art. 7 ust. 1 u.o.h.n., zgodnie z którym zakaz nie obowiązuje w kolejne dwie niedziele poprzedzające pierwszy dzień Bożego Narodzenia, w niedzielę bezpośrednio poprzedzającą pierwszy dzień Wielkiej Nocy, w ostatnią niedzielę w styczniu, kwietniu, czerwcu i sierpniu. W razie zbiegu dwóch podstaw: handlowa niedziela, w którą przypada święto wymienione $\mathrm{w}$ analizowanej ustawie, zakaz sformułowany $\mathrm{w}$ art. 5 u.o.h.n. ma zastosowanie (art. 7 ust. 2 u.o.h.n.). Oznacza to, że w handlową niedzielę, w którą przypada święto obowiązuje zakaz handlu oraz wykonywania czynności związanych $\mathrm{z}$ handlem, a także powierzanie tych czynności pracownikowi.

1.3. Na tle powyższych ustaleń należy dokonywać oceny konstytucyjności art. 5 u.o.h.n. Jak zauważa Trybunał Konstytucyjny, ustawodawca dysponuje na gruncie Konstytucji szerokim zakresem swobody regulowania życia społeczno-gospodarczego, w tym stosunków pracy (zob. wyrok TK z 26 maja 2010 r., sygn. akt P 29/08). O naruszeniu tej swobody można by mówić dopiero wówczas, gdyby wybrane przez ustawodawcę rozwiązanie godziło i to w sposób nadmierny (nieproporcjonalny lub naruszający istotę prawa lub wolności) w konstytucyjne prawa i wolności jednostki. Tymczasem w wypadku kwestionowanego przez Wnioskodawcę rozwiązania, polegającego na wprowadzeniu i sukcesywnym 
rozszerzaniu zakazu handlu w niedziele i święta, tak się nie dzieje. Niewątpliwie kwestionowany przepis, przewidujący zakaz handlu w niedziele i święta, ingeruje w wolność prowadzenia działalności gospodarczej, chronionej w art. 22 Konstytucji. Stanowi to również ograniczenie wolności świadczenia pracy przez pracowników realizujących swoje zadania w placówkach handlowych. Jednak nie można uznać, że kwestionowana regulacja ogranicza konstytucyjną wolność wykonywania pracy (art. 65 ust. 1 Konstytucji) w sposób konstytucyjnie niedopuszczalny. Jak już wspominano, ingerencja w sferę wolności pracy wymaga powiązania ograniczenia z ochroną jednej z wartości czy interesów wskazanych w art. 31 ust. 3, zachowania wymogu niezbędności (proporcjonalności) ograniczenia, oraz poszanowanie „istoty” regulowanej wolności (zob. wyroki TK z: 23 czerwca 1999 r., sygn. akt SK 30/99; 19 października 1999 r., sygn. akt SK 4/99; 19 marca 2001 r., sygn. akt K 32/00; 26 lipca 2004 r., sygn. akt U 16/02; 18 października 2010 r., sygn. akt K 1/09).

Zakaz handlu w niedziele i święta ma na celu zapewnienie pracownikom tego sektora odpowiedniego, cyklicznego wypoczynku. Jak wskazuje ustawodawca w uzasadnieniu projektu ustawy o ograniczeniu handlu w niedziele, konieczność pracy w niedziele uznawana jest przez pracowników za czynnik stresogenny, utrudnia godzenie życia zawodowego i rodzinnego oraz przyczynia się do przewlekłego stresu i zmęczenia, wywołując niepożądane skutki zdrowotne (druk sejmowy nr 870/VIII kad., s. 2). Można przyjąć, że z punktu widzenia relacji społecznych zapewnienie wolnej niedzieli ma szczególne znaczenie dla ustawodawcy. Sprzyja efektywniejszemu wypoczynkowi oraz możliwości wypełniania ról pozazawodowych pracownika. Zakaz handlu w niedziele odpowiada zatem konstytucyjnemu prawu do wypoczynku. Co więcej, przyjęte rozwiązanie normatywne stanowi standard regulacji praw pracowniczych przewidzianych $\mathrm{w}$ innych przepisach prawa, jak np. w art. $151^{9}$ ustawy z dnia 26 czerwca 1974 r. - Kodeks pracy (t.j. Dz. U. 2018, poz. 917; dalej: Kodeks pracy, k.p.), w którym ustawodawca wskazuje niedziele i święta jako dni wolne od pracy, czy w ustawie o dniach wolnych od pracy, zgodnie z którą takimi dniami są niedziele oraz wymienione w niej wyczerpująco dni świąteczne. Praca w niedziele i święta jest dozwolona jedynie w wyjątkowych przypadkach, określonych w art. $151^{10}$ k.p., a zatrudnianie pracowników w dni ustawowo wolne od pracy w innych sytuacjach aniżeli określone w art. $151^{10}$ k.p. uważane jest za wykroczenie (art. 281 pkt 5 k.p.). Na gruncie przepisów Kodeksu pracy zatrudnianie pracowników w niedziele i święta jest dopuszczalne ze szczególnych powodów, które wynikają z systemu organizacji pracy (praca w ruchu ciągłym, praca zmianowa, praca wyłącznie w piątki, soboty, niedziele i święta - art. $151^{10}$ pkt 2-3 i 10 k.p), rodzaju pracy (w transporcie i komunikacji - art. $151^{10}$ pkt 5 k.p., w zakładowych strażach pożarnych i zakładowych służbach ratowniczych - art. $151^{10}$ pkt 6 k.p., przy pilnowaniu mienia lub ochronie osób - art. $151^{10}$ pkt 7 k.p., w rolnictwie i hodowli - art. $151^{10}$ pkt 8 k.p.), szczególnych potrzeb pracodawcy (konieczność prowadzenia akcji ratowniczej 
dla ochrony życia lub zdrowia ludzkiego albo dla ochrony mienia lub usunięcia awarii - art. $151^{10}$ pkt 1 k.p., przy niezbędnych remontach - art. $151^{10}$ pkt 4 k.p.), użyteczności społecznej i konieczności zaspokajania codziennych potrzeb ludności (placówki handlowe, zakłady świadczące usługi dla ludności, gastronomia, zakłady hotelarskie, zakłady komunalne, jednostki gospodarki komunalnej, zakłady opieki zdrowotnej i inne placówki służby zdrowia przeznaczone dla osób, których stan zdrowia wymaga zapewnienia całodobowych lub całodziennych świadczeń zdrowotnych, jednostki organizacyjne pomocy społecznej oraz jednostki organizacyjne wspierania rodziny i systemu pieczy zastępczej, zapewniające całodobową opiekę, zakłady prowadzące działalność w zakresie kultury, oświaty, turystyki i wypoczynku - art. $151^{10}$ pkt 9 k.p.). O wyjątkowym dla ustawodawcy znaczeniu niedzieli świadczą również pozostałe przepisy Kodeksu pracy, które regulują pracę w niedziele i święta. Mimo że dopuszcza on na zasadzie wyjątku pracę $\mathrm{w}$ dni ustawowo wolne, to jednocześnie zobowiązuje pracodawcę do zapewnienia pracownikom rekompensaty za pracę w tych dniach (art. 151 ${ }^{11}$ k.p.) oraz zapewnienia co najmniej raz na 4 tygodnie niedzieli wolnej od pracy (art. $151^{12}$ k.p.). Nie można zatem znaleźć uzasadnienia dla regulacji zgodnej z intencją Wnioskodawcy, prowadzącej do pozbawienia pracowników całego sektora handlu prawa do wypoczynku w niedziele, skoro praca w ten dzień $\mathrm{w}$ innych gałęziach gospodarki jest traktowana przez ustawodawcę na zasadzie wyjątku, podyktowanego koniecznością zapewnienia istotnych potrzeb społecznych. W art. $151^{10}$ k.p., zawierającym wykaz prac, które można wykonywać w dni wolne od pracy, wyraźnie jest mowa o „dozwoleniu” pracy w niedziele i święta, z czego wynika, że innych rodzajów prac (niewymienionych w katalogu wyłączeń $\mathrm{z}$ art. $151^{10}$ k.p.) nie można wykonywać $\mathrm{w}$ niedziele i święta. W kwestionowanym przepisie art. 5 u.o.h.n. ustawodawca zatem w sposób spójny z ogólnymi przepisami prawa pracy i konsekwentny odniósł się do zagadnienia prawa do wypoczynku. Nie bez znaczenia dla jego gwarancji jest bowiem wyznaczenie jednego w tygodniu, wspólnego dla wszystkich pracowników, społecznie akceptowalnego dnia wolnego od pracy, jakim jest niedziela, kiedy wypoczywają także pozostali członkowie rodziny. Wprowadzenie niczym nieograniczonej wolności pracy prowadziłoby, z perspektywy rozważanego problemu konstytucyjnego, do nadmiernego obciążenia pracowników, którzy nie mogą swobodnie organizować czasu pracy. W konsekwencji wiodłoby to także do nadmiernego ograniczenia lub pozbawienia innego konstytucyjnie chronionego prawa - prawa do wypoczynku. W tej sytuacji wolność pracy musi zostać ograniczona na rzecz innej wartości, którą afirmuje ustrojodawca w art. 66 ust. 2 Konstytucji. Ustanowiony zakaz ma przyczyniać się do pełniejszej realizacji nie tylko konstytucyjnego prawa do wypoczynku (art. 66 ust. 2 Konstytucji), lecz także sprzyjać ochronie rodziny, do której została zobowiązana Rzeczpospolita Polska (art. 18 Konstytucji), zapewnieniu bezpiecznych i higienicznych warunków pracy (art. 66 ust. 1 Konstytucji), ochronie zdrowia (art. 68 ust. 1 Konstytucji) czy realizacji wolności 
religijnej (art. 53 ust. 1 i 2 Konstytucji). Kwestionowana regulacja spełnia zatem jeden $\mathrm{z}$ wymogów zasady proporcjonalności, jakim jest konieczność wprowadzenia regulacji ustawodawczej. Ustanowione ograniczenie jest niezbędne dla ochrony interesu publicznego, z którym jest powiązane.

Kwestionowany przepis spełnia również wymóg przydatności zastosowanego ograniczenia. Zakaz przewidziany w art. 5 u.o.h.n. w sposób skuteczniejszy, w porównaniu ze stanem prawnym obowiązującym przed wejściem w życie ustawy o ograniczeniu handlu w niedziele, realizuje zamierzenia ustawodawcy, polegające na zapewnieniu wolnej niedzieli oraz dni świątecznych. Jak podkreśla się w uzasadnieniu projektu ustawy o ograniczeniu handlu w niedziele, dotychczas obowiązujący zakaz handlu (uchylony ustawą o ograniczeniu handlu $\mathrm{w}$ niedziele art. $151^{9 \mathrm{a}} \S 1$ k.p., obowiązujący na mocy ustawy z dnia 24 sierpnia 2007 r. o zmianie ustawy - Kodeks pracy, Dz. U. nr 176, poz. 1239) nie dotyczył placówek handlowych przy wykonywaniu prac koniecznych ze względu na ich użyteczność społeczną i codzienne potrzeby ludności (uchylony art. 151 ${ }^{\text {aa }} \$ 3$ k.p.), w efekcie czego handel w niedziele był prawnie dopuszczalny i stanowił zjawisko powszechnie obecne (druk sejmowy nr 870/VIII kad., s. 1). Chcąc zachować wyjątkowy charakter pracy w niedziele, ustawodawca wprowadził nie tylko zakaz zatrudniania w niedziele, w rozumieniu przepisów Kodeksu pracy, lecz ustanowił zakaz handlu, który dotyczy pracy w placówkach handlowych bez względu na rodzaj podstawy prawnej jej wykonywania. W ten sposób eliminuje możliwość wykonywania pracy w dni objęte zakazem przez osoby zatrudniane na podstawie innych form świadczenia pracy niż uregulowane w Kodeksie pracy.

Ustanawiając niedzielę dniem wolnym od handlu, ustawodawca zapewnił jednak dostateczne gwarancje wolności pracy. Kwestionowanym przepisem rozszerzył jedynie obowiązujący dotychczas zakaz pracy w placówkach handlowych, zmierzając do skuteczniejszej jego realizacji. Oznacza to, że aktywność zawodowa w sektorze handlu może być realizowana we wszystkich dniach tygodnia z wyłączeniem co do zasady niedziel i dni świątecznych. Nie jest to jednak zakaz absolutny, na co wskazują wyłączenia $\mathrm{z}$ art. 7 ust. 1, art. 8 ust. 1, art. 16 ust. 1 i art. 17 ust. 1 u.o.h.n., dopuszczające handel w wybrane niedziele roku. Należy również przypomnieć, że zakaz handlu nie obejmuje przedsiębiorcy będącego osobą fizyczną, który podejmuje czynności handlowe osobiście, we własnym imieniu i na własny rachunek. Wprowadzając zakaz handlu w niedziele i święta, ustawodawca zapewnia jednocześnie korzyści społeczne, jak możliwość rodzinnego spędzania czasu, eliminację utrudnień w godzeniu życia zawodowego i rodzinnego (np. przy organizowaniu opieki nad dziećmi), zmniejszenie zmęczenia, bardziej ergonomiczne warunki pracy czy prawo do wypoczynku. Zamierzone przez ustawodawcę efekty pozostają zatem w odpowiedniej proporcji w stosunku do ciężaru, jaki wiąże się z ograniczeniem handlu w niedziele i święta. Warto także podkreślić, że w uzasadnieniu projektu ustawy o zakazie handlu w niedziele i święta ustawodawca powołuje się na przeprowadzone konsultacje z organi- 
zacjami i zrzeszeniami pracodawców, partnerami społecznymi, środowiskami naukowymi, które udzieliły poparcia dla projektowanych zmian w omawianej kwestii (druk sejmowy nr 870/VIII kad., s. 16-17). Nie można zatem przyjąć, że kwestionowany przepis pozbawia prawa do wykonywania określonego zawodu i tym samym nieproporcjonalnie narusza chronioną w art. 65 ust. 1 Konstytucji wolność.

\section{- 2. Zarzut niezgodności art. 6 ust. 1 u.o.h.n. z art. 32 ust. 1 Konstytucji (zasada równości)}

Odnosząc się do zarzutu naruszenia przez art. 6 ust. 1 u.o.h.n. konstytucyjnej zasady równości wobec prawa, trzeba wskazać, że - jak już zostało wspomniane wyżej - ustawodawca dysponuje na gruncie Konstytucji szerokim zakresem swobody regulowania życia społeczno-gospodarczego. „W odniesieniu do zasady równości oznacza to, że wybór kryteriów różnicowania w poszczególnych dziedzinach życia społeczno-gospodarczego należy do ustawodawcy. Prawodawca, nakładając obowiązki lub przyznając określone uprawnienia, nie może jednak określać kręgu podmiotów objętych tymi obowiązkami lub uprawnieniami w sposób dowolny. Ustanowione obowiązki oraz przyznane uprawnienia powinny - w miarę możliwości - obejmować wszystkie podmioty charakteryzujące się daną wspólną cechą istotną z punktu widzenia danej regulacji prawnej. Jednocześnie wszelkie odstępstwa od zakazu różnicowania podmiotów podobnych muszą mieścić się w granicach wyznaczonych przez [...] kryteria dopuszczalnego różnicowania tych podmiotów" (wyrok TK z 26 maja 2010 r., sygn. akt P 29/08). Dane kryterium może stanowić podstawę różnicowania podmiotów prawa, charakteryzujących się wspólną cechą istotną, jeżeli pozostaje ono w racjonalnym związku z celem i treścią danej regulacji, waga interesu, któremu różnicowanie ma służyć, pozostaje w odpowiedniej proporcji do wagi interesów, które zostaną naruszone w wyniku wprowadzonego różnicowania, oraz kryterium różnicowania pozostaje w związku z innymi wartościami, zasadami czy normami konstytucyjnymi, uzasadniającymi odmienne traktowanie podmiotów podobnych (wyroki TK z: 16 grudnia 1997 r., sygn. akt K 8/97; 29 czerwca 2001 r., sygn. K 23/0; 7 kwietnia 2003 r., sygn. akt P 7/02).

Kwestionowany przepis zawiera katalog wyłączeń ustawowych spod zakazu handlu w niedziele i święta w placówkach handlowych. Wymienia trzydzieści dwa przypadki, w których działalność handlowa może być prowadzona ze względu na jej użyteczność społeczną, powiązanie z innego typu aktywnością lub realizacją prawa do wypoczynku pracowników pozostałych sektorów gospodarki. Działalność handlowa prowadzona przez wskazane w tym przepisie podmioty zaspokaja istotne potrzeby społeczne, które z punktu widzenia ustawodawcy zostały uznane za niezbędne, racjonalne bądź pożyteczne. Wśród wyłączeń znalazły się m.in. placówki handlowe zaspokajające potrzeby zakupowe osób, które mają ograniczone możliwości ich realizacji. Należą do nich placówki handlowe 
w zakładach leczniczych (pkt 12), zakładach penitencjarnych (pkt 18), na terenie jednostek wojskowych (pkt 19), w obiektach infrastruktury krytycznej (pkt 8), w zakładach hotelarskich (pkt 9), w portach i przystaniach morskich (pkt 13), w portach lotniczych (pkt 15), w strefach wolnocłowych (pkt 16), w środkach transportu, na statkach, statkach powietrznych i morskich budowlach hydrotechnicznych (pkt 17). Wśród dopuszczalnych wyłączeń znalazły się także placówki handlowe, w których sprzedawane są produkty rolno-spożywcze (pkt 22, pkt 30-32) oraz, w wyznaczonym okresie roku, maszyny rolnicze i części zamienne (pkt 14), a także ryby w pierwszej sprzedaży (pkt 14), co zostało podyktowane specyficznymi wymaganiami tej gałęzi gospodarczej, jaką jest rolnictwo i rybołówstwo. Ponadto wymienia się placówki handlowe, których działalność jest niezbędna dla realizacji wypoczynku czy wydarzeń rekreacyjno-kulturalnych: placówki prowadzące działalność w zakresie kultury, sportu, oświaty, turystyki i wypoczynku (pkt 10), placówki handlowe organizowane wyłącznie na potrzeby festynów, jarmarków i innych imprez okolicznościowych (pkt 11), placówki handlowe, których przeważająca działalność polega na handlu pamiątkami lub dewocjonaliami (pkt 5), placówki prowadzące działalność gastronomiczną (pkt 29), oraz piekarnie, cukiernie i lodziarnie (pkt 28). Ze względu na ważną funkcję społeczną w katalogu dopuszczalnych wyłączeń znalazły się także stacje paliw płynnych (pkt 1), apteki i punkty apteczne (pkt 3), zakłady lecznicze dla zwierząt (pkt 4), hurtownie farmaceutyczne (pkt 23), zakłady pogrzebowe (pkt 26) oraz placówki pocztowe (pkt 7). Ustawodawca wyłączył także spod zakazu handlu placówki handlowe, których przeważająca działalność polega na handlu prasą, biletami komunikacji miejskiej, wyrobami tytoniowymi, kuponami gier losowych i zakładów wzajemnych (pkt 6), handlu kwiatami (pkt 2), w tym także kwiatami, wiązankami, wieńcami i zniczami przy cmentarzach (pkt 25). Z oczywistych względów wyłączenie dotyczy także handlu za pośrednictwem sklepów internetowych i platform internetowych (pkt 20) oraz handlu towarami z automatu (pkt 21), których prowadzenie nie generuje konieczności zatrudniania pracownika we wskazane dni wolne od pracy. Wreszcie, ustawodawca wyłącza spod zakazu przedsiębiorców będących osobami fizycznymi, którzy prowadzą działalność handlową osobiście, we własnym imieniu i na własny rachunek (pkt 27). Nie można zatem zgodzić się z Wnioskodawcą, że przedstawiona w art. 6 u.o.h.n. grupa podmiotów została wyróżniona według nieznanych kryteriów, w sposób arbitralny i tym samym dyskryminujący ze względu na branżę, strukturę organizacyjną lub strukturę właścicielską (wniosek, s. 13). Ustawodawca dokonał wyboru podmiotów zgodnie z przesłanką zaspokajania potrzeb ludności, które w jego ocenie są uzasadnione względami ochrony zdrowia, użyteczności społecznej bądź wynikają z rekreacyjnego charakteru dnia wolnego od pracy. Jak już zostało wyżej podkreślone, wprowadzenie zróżnicowania podmiotów handlowych pozostaje w związku z celem realizowanym przez ustawodawcę w ustawie o ograniczeniu handlu w niedziele, jakim jest zapew- 
nienie dnia wypoczynku, sprzyjającemu zdrowiu i bezpieczeństwu pracowników. Za konstytucyjnością przyjętego rozwiązania przemawia fakt, że ustawodawca ograniczył grupę wyłączeń do katalogu podmiotów, których działalność w niedziele i święta jest racjonalnie uzasadniona potrzebami społecznymi i pozostają one w odpowiednim związku z innymi wartościami konstytucyjnymi. Funkcjonowanie w niedziele i święta wybranych punktów handlowych jest uzasadnione z punktu widzenia ochrony zdrowia (art. 68 ust. 1 Konstytucji), zapewnienia bezpieczeństwa i porządku publicznego (art. 31 ust. 3 Konstytucji) czy prawa do bezpiecznych i higienicznych warunków pracy (art. 66 ust. 1 Konstytucji).

\section{- 3. Zarzut niezgodności art. 3 pkt 7 u.o.h.n. z art. 2 Konstytucji (zasada określoności prawa)}

Kwestionowany przepis ustawy o ograniczeniu handlu w niedziele, w ocenie Wnioskodawcy, jest niespójny z regulacją przewidzianą w Kodeksie pracy, a w konsekwencji uniemożliwia jego prawidłową interpretację i implementację. W art. 3 pkt 7 u.o.h.n. wskazuje się, że niedziele i święta, których dotyczy zakaz $\mathrm{z}$ art. 5 u.o.h.n., obejmuje okres 24 kolejnych godzin przypadających odpowiednio między godziną $24.00 \mathrm{w}$ sobotę a godziną $24.00 \mathrm{w}$ niedzielę i między godziną $24.00 \mathrm{w}$ dniu bezpośrednio poprzedzającym święto a godziną $24.00 \mathrm{w}$ święto. Natomiast w art. $151^{9} \$ 2$ k.p. ustawodawca za pracę w niedzielę i święto, w przypadkach, o których mowa w art. $151^{10} \mathrm{k}$.p., uważa pracę wykonywaną między godziną $6.00 \mathrm{w}$ tym dniu a godziną $6.00 \mathrm{w}$ następnym dniu (chyba że u danego pracodawcy została ustalona inna godzina). Zdaniem Wnioskodawcy terminy doby niedzielnej i świątecznej zostały konkurencyjnie zdefiniowane w obu aktach prawnych (wniosek, s. 14).

Nie kwestionując podniesionego przez Wnioskodawcę zróżnicowania sposobu, w jaki ustawodawca definiuje niedzielę w przywołanych aktach prawnych, nie można jednak zgodzić się ze stawianym zarzutem naruszenia art. 2 Konstytucji, gdyż porównywane przepisy mają odmienny przedmiot regulacji. Należy zwrócić uwagę, że ustawodawca, regulując w art. $151^{9} \$ 2$ k.p. granice czasowe niedzieli i świąt, odnosi je do unormowania art. $151^{10} \mathrm{k}$.p. przewidującego dopuszczalność pracy pracowników w niedziele i święta. Przepis art. $151^{10}$ k.p. określa przypadki, w których wyjątkowo dopuszczalna jest praca w niedziele i święta. Zatem w sytuacjach przewidzianych w art. $151^{10} \mathrm{k} . \mathrm{p}$. możliwe jest wykonywanie pracy, po pierwsze, wyłącznie przez pracowników, rozumianych zgodnie z przepisami Kodeksu pracy (osoba fizyczna zatrudniona na podstawie umowy o pracę, spółdzielczej umowy o pracę, powołania, wyboru, mianowania art. 2 k.p.), a po drugie, dotyczy to czynności, które ze względu na swój charakter powinny być wykonywane bez przerwy. Należą do nich prace wykonywane: „1) w razie konieczności prowadzenia akcji ratowniczej w celu ochrony życia lub zdrowia ludzkiego, ochrony mienia lub środowiska albo usunięcia awarii; 2) w ruchu ciągłym; 3) przy pracy zmianowej; 4) przy niezbędnych remontach; 
5) w transporcie i w komunikacji; 6) w zakładowych strażach pożarnych i w zakładowych służbach ratowniczych; 7) przy pilnowaniu mienia lub ochronie osób; 8) w rolnictwie i hodowli; 9) przy wykonywaniu prac koniecznych ze względu na ich użyteczność społeczną i codzienne potrzeby ludności, w szczególności w: [...] b) zakładach świadczących usługi dla ludności, c) gastronomii, d) zakładach hotelarskich, e) jednostkach gospodarki komunalnej, f) zakładach opieki zdrowotnej i innych placówkach służby zdrowia przeznaczonych dla osób, których stan zdrowia wymaga całodobowych lub całodziennych świadczeń zdrowotnych, g) jednostkach organizacyjnych pomocy społecznej oraz jednostkach organizacyjnych wspierania rodziny i systemu pieczy zastępczej zapewniających całodobową opiekę, h) zakładach prowadzących działalność w zakresie kultury, oświaty, turystyki i wypoczynku; 10) w stosunku do pracowników zatrudnionych w systemie czasu pracy, w którym praca jest świadczona wyłącznie w piątki, soboty, niedziele i święta; 11) przy wykonywaniu prac: a) polegających na świadczeniu usług z wykorzystaniem środków komunikacji elektronicznej w rozumieniu przepisów o świadczeniu usług drogą elektroniczną lub urządzeń telekomunikacyjnych w rozumieniu przepisów prawa telekomunikacyjnego, odbieranych poza terytorium Rzeczypospolitej Polskiej, jeżeli zgodnie z przepisami obowiązującymi odbiorcę usługi, dni, o których mowa w art. $151^{9} \$ 1$, są u niego dniami pracy, b) zapewniających możliwość świadczenia usług, o których mowa w lit. a”. Wynika $\mathrm{z}$ tego, że granice czasowe niedzieli i świąt uregulowane w art. $151^{9} \$ 2$ k.p. odnoszą się jedynie do przypadków pracy w niedziele i święta, o których mowa $\mathrm{w}$ art. $151^{10}$ k.p. Natomiast pojęcie doby niedzielnej i świątecznej uregulowane w ustawie o ograniczeniu handlu w niedziele odnosi się do zakazu (a nie dozwolenia) wykonywania pracy i to tylko w określonej dziedzinie, którą jest handel oraz wykonywanie czynności związanych $\mathrm{z}$ handlem w niedziele i święta w placówkach handlowych. Praca w handlu nie spełnia żadnej z cech wymienionych w katalogu wyjątków dopuszczających pracę w niedziele i święta (przewidziany w art. $151^{10}$ k.p.). Nie obejmuje pracodawców zatrudniających pracowników w ruchu ciągłym, pracy zmianowej, transporcie i komunikacji, w zakładowych strażach pożarnych i w zakładowych służbach ratowniczych, przy pilnowaniu mienia i ochronie osób, w rolnictwie i hodowli, w stosunku do pracowników zatrudnionych w weekendowo-świątecznym systemie czasu pracy, przy wykonywaniu prac koniecznych ze względu na ich użyteczność społeczną i codzienne potrzeby ludności (art. $151^{10}$ pkt 2-9 k.p.). Nie polega na wykonywaniu pracy przez pracowników zatrudnionych w systemie czasu pracy, w którym praca jest świadczona wyłącznie w piątki, soboty niedziele i święta (art. $151^{10}$ pkt 10 k.p.). Nie dotyczy również zatrudniania pracowników w niedziele i święta w sytuacjach odbiegających od normy, tj. w razie konieczności prowadzenia akcji ratowniczej w celu ochrony życia lub zdrowia ludzkiego, ochrony mienia lub środowiska albo usunięcia awarii oraz przy niezbędnych remontach (art. 151 ${ }^{10}$ pkt 1 i 4 k.p.). 
Ponadto, kwestionowany art. 3 pkt 7 u.o.h.n. nie przewiduje żadnych odstępstw od wyznaczonych ram godzinowych świątecznej doby, natomiast przepis $151^{9} \$ 2$ k.p., w związku z tym, że odnosi się do wyjątkowej dopuszczalności pracy w niedziele i święta, zezwala pracodawcom na ustalenie innych godzin rozpoczęcia i zakończenia pracy w dni ustawowo wolne od pracy. Zgodnie z nim pracodawca ma także prawo przyjąć kalendarzowe normy określania dni wolnych od pracy, według których początek każdej doby wyznacza północ. Może przyjąć też inną niż 6.00 (norma ustawowa) lub 24.00 (norma kalendarzowa) godzinę rozpoczęcia dnia wolnego od pracy. Nie może jedynie ustalić innych, niż powszechnie obowiązujące, miar czasu obliczania doby (24 godziny). Nie może również przyjąć jako początku doby, określającej dzień ustawowo wolny od pracy - godziny, która przypada w innym dniu tygodnia niż niedziela lub święto wynikające z rozkładu kalendarza (zob. A. Świątkowski, Kodeks pracy, op. cit., komentarz do art. $151^{9 \mathrm{~b}}$ ). Z powyższego wynika, że pracownik, w rozumieniu przepisów Kodeksu pracy, będzie mógł wykonywać pracę w niedzielę i święta tylko w sytuacjach przewidzianych w art. $151^{10}$ k.p., w godzinach przewidzianych Kodeksem pracy lub ustalonych z pracodawcą. A contrario, jeśli nie zaistnieją okoliczności przewidziane $\mathrm{w}$ art. $151^{10} \mathrm{k} . \mathrm{p}$., praca wykonywana między godziną $6.00 \mathrm{w}$ niedzielę i święta a godziną 6.00 w następnym dniu jest niedozwolona. Natomiast, na podstawie art. 5 i art. 3 pkt 7 u.o.h.n. praca polegająca na handlu lub innych czynnościach z nim związanych, powierzana zarówno pracownikom, jak i innym osobom wykonującym pracę w ramach zatrudnienia niepracowniczego, będzie zakazana w niedziele i święta w godzinach 24.00 dnia poprzedzającego je, a 24.00 odpowiednio w niedzielę lub święto. Innymi słowy, należy spełnić odmienne przesłanki, aby wykonywanie pracy w niedziele i święta było dozwolone na podstawie art. $151^{9}$ $\$ 2$ k.p. oraz zgodne $\mathrm{z}$ art. 3 pkt 7 u.o.h.n. Ich wypełnienie nie jest wzajemnie sprzeczne, gdyż dotyczy odmiennych sytuacji. W związku z tym ustawodawca nie naruszył zasady określoności przepisów prawa, regulując kwestionowany przepis odmiennie od określonych w Kodeksie pracy granic czasowych niedziel i świąt.

\section{- 4. Zarzut niezgodności art. 18 u.o.h.n. z art. 2 Konstytucji (zasada odpowiedniej vacatio legis)}

Jak podkreśla Trybunał Konstytucyjny w swoim orzecznictwie, społeczny sens instytucji vacatio legis polega na tym, aby zapewnić obywatelom odpowiedni czas na zaznajomienie się z nowymi przepisami prawnymi oraz na dostosowanie się do wymagań, jakie niosą ze sobą nowe regulacje. Zgodnie z utrwaloną linią orzeczniczą Trybunału „odpowiedniość” vacatio legis należy rozpatrywać w związku z możliwością pokierowania swoimi prawami z uwzględnieniem treści nowych przepisów. Wymóg zachowania vacatio legis należy bowiem odnosić nie do ochrony adresata normy prawnej przed pogorszeniem jego sytuacji, ale do jego możliwości zapoznania się z nowymi przepisami oraz możliwości adaptacyjnych, które bywają zróżnicowane (zob. wyroki TK z: 16 czerwca 1999 r., sygn. akt 
P 4/98; 25 marca 2003 r., sygn. akt U 10/01). Przy ocenie „odpowiedniości” vacatio legis - w ramach kontroli konstytucyjności wprowadzenia nowych przepisów do porządku prawnego - istotne znaczenie ma przedmiot i treść nowych regulacji, stopień ingerencji nowych przepisów prawa w dotychczasową sytuację prawną jednostki, a także to, jak dalece różnią się one od unormowań dotychczasowych i ile czasu potrzeba, by ich adresaci dostosowali się do nowych postanowień (zob. wyroki TK z: 20 grudnia 1999 r., sygn. akt K 4/99; 30 czerwca 2009 r., sygn. akt K 14/07). Trybunał Konstytucyjny niejednokrotnie podkreślał, że ocena, czy przewidziana w ustawie vacatio legis jest odpowiednia, powinna zostać dokonana ze szczególną ostrożnością: „Jeżeli vacatio legis odpowiada generalnym założeniem przyjętym w art. 4 ust. 1 ustawy z dnia 20 lipca 2000 r. o ogłaszaniu aktów normatywnych i niektórych innych aktów prawnych, uznanie przez Trybunał, że doszło do naruszenia art 2 Konstytucji mogłoby nastąpić tylko w rażących przypadkach" (wyrok TK z 16 września 2003 r., sygn. akt K 55/02).

Przy ocenie stawianych przez Wnioskodawców zarzutów w pierwszej kolejności należy podkreślić zachowanie przez ustawodawcę minimalnego standardu vacatio legis, wyznaczonego ustawą z dnia 20 lipca 2000 r. o ogłaszaniu aktów normatywnych i niektórych innych aktów prawnych (Dz. U. Nr 62, poz. 718, ze zm.), która w art. 4 przyjmuje, że dla wejścia w życie aktów normatywnych, zawierających przepisy powszechnie obowiązujące, przewidziany jest - co do zasady - czternastodniowy okres spoczynku. Tymczasem wprowadzeniu w życie kwestionowanej ustawy towarzyszyło pięćdziesięciodniowe vacatio legis.

Ponadto należy zwrócić uwagę na cel ustawy o ograniczeniu handlu w niedzielę. Wynika on z treści art. 5 i art. 6 u.o.h.n., zgodnie z którym ustanawia się zakaz handlu oraz zakaz wykonywania czynności związanych z handlem z wieloma wyjątkami odnoszącymi się do rodzajów placówek handlowych, których zakaz nie obejmuje ze względu na specyfikę prowadzonej działalności gospodarczej. $\mathrm{W}$ istocie w art. 5 u.o.h.n. ustawodawca zmierza do zakazu prowadzenia działalności handlowej w niedziele poza niedzielami handlowymi. Zakaz ten jednak został wprowadzony etapami. Jak przedstawiono wyżej, cel ustawodawcy zostanie osiągnięty w pełni dopiero od 2020 r. Do tego czasu ograniczenie handlu będzie przebiegało dwuetapowo. W 2018 r. zakaz nie obejmuje pierwszej i ostatniej niedzieli miesiąca, natomiast w 2019 r. zakaz nie będzie obowiązywał w ostatnią niedzielę każdego miesiąca. Zatem ekonomiczno-społeczne skutki wprowadzanej ustawy, o których wspomina Wnioskodawca, będą odczuwalne stopniowo. Ustawodawca daje $\mathrm{w}$ ten sposób możliwość dostosowania się do ograniczenia handlu w placówkach handlowych, w tym weryfikacji prognoz finansowych i organizacyjnych podmiotów gospodarczych, których działalność koncentruje się na handlu bądź na podejmowaniu czynności okołosprzedażowych.

Wprowadzony w art. 5 u.o.h.n. zakaz handlu w niedziele i święta nie jest regulacją dotychczas nieznaną $\mathrm{w}$ polskim porządku prawnym. Kwestionowane unormowanie nawiązuje do uchylonego ustawą o ograniczeniu handlu w nie- 
dziele art. $151^{\text {9a }}$ k.p. (obowiązujący na mocy ustawy z dnia 24 sierpnia 2007 r. o zmianie ustawy - Kodeks pracy, Dz. U. nr 176, poz. 1239), przewidującego zakaz świadczenia pracy w święta w placówkach handlowych. Zakazem tym ustawodawca objął również pracę w niedzielę, jeżeli w tym dniu wypadnie święto. Natomiast praca w niedzielę, na którą święto nie przypada, zgodnie z treścią nieobowiązującego art. $151^{\text {a }} \$ 3$ k.p. była dozwolona w placówkach handlowych przy wykonywaniu prac koniecznych ze względu na ich użyteczność społeczną i codzienne potrzeby ludności. Mocą ustawy o ograniczeniu handlu w niedziele zakaz ten, co do zasady, został jedynie rozszerzony, gdyż odnosi się do powierzania czynności związanych $\mathrm{z}$ handlem nie tylko pracownikom, lecz także osobom wykonującym pracę w ramach zatrudnienia niepracowniczego, cywilnoprawnego oraz pracownikom tymczasowym niezatrudnionym przez przedsiębiorców prowadzących działalność handlową. Jak wynika z uzasadnienia projektu ustawy o ograniczeniu handlu w niedziele, w konsekwencji dopuszczalnych w Kodeksie pracy wyjątków, handel w niedziele stał się prawnie dopuszczalny i stanowił zjawisko powszechne (druk sejmowy nr 870/VIII kad., s. 1). Uznając dotychczasowe rozwiązania za niewystarczające, ustawodawca sięgnął po środki, które bardziej skutecznie zapewnią potrzebę pracowników posiadania wolnej niedzieli (ibidem, s. 2). Zatem stopień ingerencji kwestionowanych przepisów w dotychczasową sytuację prawną jednostki nie jest aż tak daleki, aby przyjętą w ustawie o ograniczeniu handlu w niedziele vacatio legis uznać za niewystarczającą.

\section{- 5. Podsumowanie}

Mając powyższe na uwadze, Sejm wnosi o stwierdzenie, że:

1) art. 3 pkt 7 i art. 18 ustawy z dnia 10 stycznia 2018 r. o ograniczeniu handlu w niedziele i święta oraz w niektóre inne dni (Dz. U. poz. 305) są zgodne $\mathrm{z}$ art. 2 Konstytucji,

2) art. 5 ustawy powołanej w punkcie 1 jest zgodny z art. 65 ust. $1 \mathrm{w}$ związku $\mathrm{z}$ art. 24 i art. 31 ust. 3 Konstytucji,

3) art. 6 ust. 1 ustawy powołanej w punkcie 1 jest zgodny z art. 32 ust. 1 Konstytucji.

Ponadto Sejm wnosi o umorzenie postępowania w pozostałym zakresie na podstawie art. 59 ust. 1 pkt 2 ustawy o organizacji i trybie postępowania przed Trybunałem Konstytucyjnym ze względu na niedopuszczalność wydania wyroku.

\section{- Bibliografia}

Banaszak B., Konstytucja Rzeczypospolitej Polskiej. Komentarz, Warszawa 2012.

Boć J., Konstytucje Rzeczypospolitej Polskiej oraz komentarz do Konstytucji RP z 1997 r., Wrocław 1998.

Garlicki L., Jarosz-Żukowska S. [w:] Konstytucja Rzeczypospolitej Polskiej. Komentarz, t. II, red. L. Garlicki, M. Zubik, Warszawa 2016. 
Góral Z., Podstawowe zasady indywidualnego prawa pracy, Warszawa 2010.

Morawska E., Klauzula państwa prawnego w Konstytucji RP na tle orzecznictwa TrybunaŁu Konstytucyjnego, Toruń 2003.

Sobczyk J. [w:] Kodeks pracy. Komentarz, red. J. Sobczyk, 2018, Legalis.

Sokolewicz W., Zubik M., Komentarz do art. 2 [w:] Konstytucja Rzeczypospolitej Polskiej. Komentarz, t. II, red. L. Garlicki, M. Zubik, Warszawa 2016.

Świątkowski A., Kodeks pracy. Komentarz, 2018, Legalis. 